\title{
ОБЗОРЫ
}

\section{MEANINGFUL ANALYSIS OF INNOVATION, BUSINESS AND ENTREPRENEURIAL ECOSYSTEM CONCEPTS}

\author{
Y. D. BURDA, I. O. VOLKOVA, E. V. GAVRIKOVA \\ Faculty of Business and Management, \\ National Research University Higher School of Economics, Moscow, Russia ${ }^{\text {a }}$
}

\begin{abstract}
Over the last decade, academic literature has seen a boom in the number of publications devoted to the notion of ecosystem, which has resulted in the emergence of various research streams and the corresponding fragmentation of the research domain. The existing variation in meanings and contradictory definitions shows the need for a thorough literature review on the three tightly related concepts of innovation ecosystem, business ecosystem and entrepreneurial ecosystem. This study is based on a mixed technique, which combines a bibliometric analysis and an in-depth investigation of papers devoted to these research streams. Through examining their theoretical background, constructing conceptual structures and performing an in-depth analysis we were able to define the essence of innovation, business and entrepreneurial ecosystems as well as their distinctive features. We then proceeded with a comparative analysis of these concepts, which allowed us to outline the existing similarities and to demarcate the concepts from an ontological perspective. This study provides definitive clarification regarding the existing conceptual mix in the field of ecosystem research, and can be used as a foundation for a further investigation of the concept.
\end{abstract}

Keywords: ecosystem, innovation ecosystem, business ecosystem, entrepreneurial ecosystem, value creation, bibliometric analysis, coopetition.

JEL: M13, O30, O36.

\section{INTODUCTION}

Over the last ten years we may observe a major shift from the creation of individual offerings towards that of complex value propositions (VP), which require inputs and effort of many economic agents [Adner, 2006; 2017; Walrave et al., 2018]. This phenomenon has

The reported study was funded by RFBR, project number 19-31-27001.

${ }^{a}$ Organization address: 26-28, Shabolovka, Faculty of Business and Management, National Research University Higher School of Economics, Moscow, 119049, Russia.

(c) Y. D. Burda, I. O. Volkova, E. V. Gavrikova, 2020

https://doi.org/10.21638/spbu18.2020.104 
received a great deal of attention from major scholars and obtained various labels: open innovations [Chesbrough, 2003] supply networks [Simchi-Levi, 2005] or innovation networks [Lee et al., 2016]. However, as it was recently shown in [Jacobides, Cennamo, Gawer, 2018] there are cases, when hierarchy or market relations cannot completely explain the nature of interfirm collaboration and their interdependence. In particular, this becomes evident in cases when users are able to choose components of the value proposition as well as their combination. This resulted in the development of the ecosystem theory, which is capable of explaining peculiarities of such collaboration among economic agents and put some clarity into the accompanying models of value creation and its capture [Adner, 2017]. The ecosystem concept provides a unique point of view on important competitive, organizational and collaborative challenges faced by firms [Jacobides, Cennamo, Gawer, 2018] and has beccome a noticeable point of discussion among strategy scholars over the past 20 years [Adner, 2017]. As a result, a wide array of various research streams has developed: "innovation ecosystem", "business ecosystem", "entrepreneurial ecosystem", "platform ecosystem", "knowledge ecosystem" and many others. These strands of research, though providing interesting lenses for analysis, undeliberately create conceptual ambiguity as they rely upon different and sometimes contradictory definitions of the ecosystem concept. As a consequence, research on ecosystems includes a fair amount of criticism directed at the very concept [Oh et al., 2016].

Therefore, there is a need for a better structure in the ecosystem research. In particular, we need to clarify the essence of the ecosystem concept, demarcate various existing research streams and establish similarities and differences between various types of ecosystems present in the existing body of knowledge. Taken together, this would allow us to bring more clarity to the existing chaotic development of the ecosystem research [Adner, 2017], to better structure the overall research field [Oh et al., 2016] and properly define the object of analysis in ecosystem studies.

For the purpose of this study we focus our attention on three dominant research streams, which create the major controversy in the existing studies on ecosystems: innovation ecosystem (IE), business ecosystem (BE) and entrepreneurial ecosystem (EE). These strands of research provide rather contradictory definitions of the concept, and scholars tend to treat them as synonyms, which leads to a noticeable critique of ecosystem notion (e.g.: [Oh et al., 2016]) and does not allow structuring the existing body of knowledge. In particular, there are a number of papers that treat IE and BE synonymously [Gawer, Cusumano, 2014; Nambisan, Baron, 2013; Overholm, 2015; Ritala et al., 2013], which is not a surprise taking into account the fact that the former is based upon the concept of business ecosystem initially introduced by [Moore, 1993]. At the same time, the notion of EE heavily relies upon strategy literature [Acs et al., 2017] - including the previously mentioned perspective of business ecosystems and the entrepreneurship itself is usually considered within the boundaries of innovation ecosystem [Nambisan, Baron, 2013].

As we can see, these three concepts heavily intersect in terms of their boundaries and common theoretical foundations. Such a fragmented and overlapping landscape of the ecosystem research creates a fruitful condition for the investigation of these concepts with a view of bringing a greater clarity and transparency to the existing research on ecosystems. This paper aims to fulfill this task through the following objectives: (1) to investigate the essence of the IE, BE and EE concepts; and (2) to outline ontological similarities and differences among them.

Our intended contribution is: (1) to outline major connections between IE, BE and EE and already established and mature literature on strategy; (2) to outline the dis- 
tinctive characteristics of each of the studied concepts and, therefore, to establish their boundaries; (3) to define major similarities and differences among IE, BE and EE phenomena with a special focus upon their internal characteristics. Taken together, this will allow future scholars to better position their research by clearly defining the object of their analysis that will ultimately result in a more structured and transparent development of the ecosystem theory.

The paper is organized as follows: first, we introduce the research methods and describe of the data; second, we provide the results of the conducted literature review; third, we outline the results of an in-depth analysis of the research devoted to each of the streams; and finally, we proceed to the conclusions, discussion and limitations of this research as well as possible avenues for further investigation of the ecosystem phenomenon.

\section{RESEARCH METHODS}

\section{Research design}

The current state of the ecosystem research is not enough structured and/or established [Oh et al., 2016]. There is a considerable conceptual ambiguity and contradictory definitions. For instance, there are scholars who treat IE and BE synonymously (e.g.: [Adner, Kapoor, 2016; Brusoni, Prencipe, 2013; Nambisan, Baron, 2013; Ritala et al., 2013; Rohrbeck, Holzle, Gemunden, 2009]), while the research on $\mathrm{EE}$ sometimes treats it as a part of IE or BE (e.g.: [Acs et al., 2017; Chepurenko, 2019]). Aimed to refine the ecosystem conceptualization and offer a more holistic point of view on types of interfirm collaboration, this study is focused on three dominant streams of the ecosystem research IE, BE and EE. In order achieve the aim so we applied a two-step approach, which included both a bibliometric and an in-depth analysis of the papers devoted to each of the outlined research streams. Such a com- plementary algorithm allowed us to combine the benefits of both broad and deep investigation of the concepts. A description of the dataset for the analysis is provided in the next section (see "Data").

We started with the bibliometric research, which is able to "...quantify the written communication process..." [Gomes et al., 2018, p. 31] and provide a ground for the following in-depth investigation [Ikpaahindi, 1985]. In our research we relied upon the metanarrative review method proposed in [Greenhalgh et al., 2005] and: (1) investigated the roots of each of the research streams in the existing managerial literature, as well as (2) examined the conceptual structure of these research domains. This allowed us to obtain a preliminary idea about the phenomenon under study and proceed to the next stage of the research.

The bibliometric analysis was performed in the graphic add-on "biblioshiny" for the package "bibliometrix" in R. Studio v. 1.2.5033 software. This package is especially suitable for science mapping when there is a case of fragmentation in the body of knowledge [Aria, Cuccurullo, 2017]. For the purpose of analysis full bibliographic data of publications was used.

First, the task of the bibliometric analysis was solved by virtue of applying a "threefields plot function" (a variation of wellknown Sankey diagrams). As a basis we took three categories of data (specified in their respective order of appearance in figures 2 , 4 and 6$)$.

(1) Authors' keywords (5 most frequently used - in order to analyze different variations of the phenomenon in question). They represent the essence of each of the studied papers from authors' point of view and are very important for understanding the perceived meaning of the phenomenon that the paper is devoted to.

(2) "Keywords plus" (10 most frequently used), which are generated automatically by a corresponding Web of Science algorithm. They should include words or phrases that appear frequently in the titles of the paper 


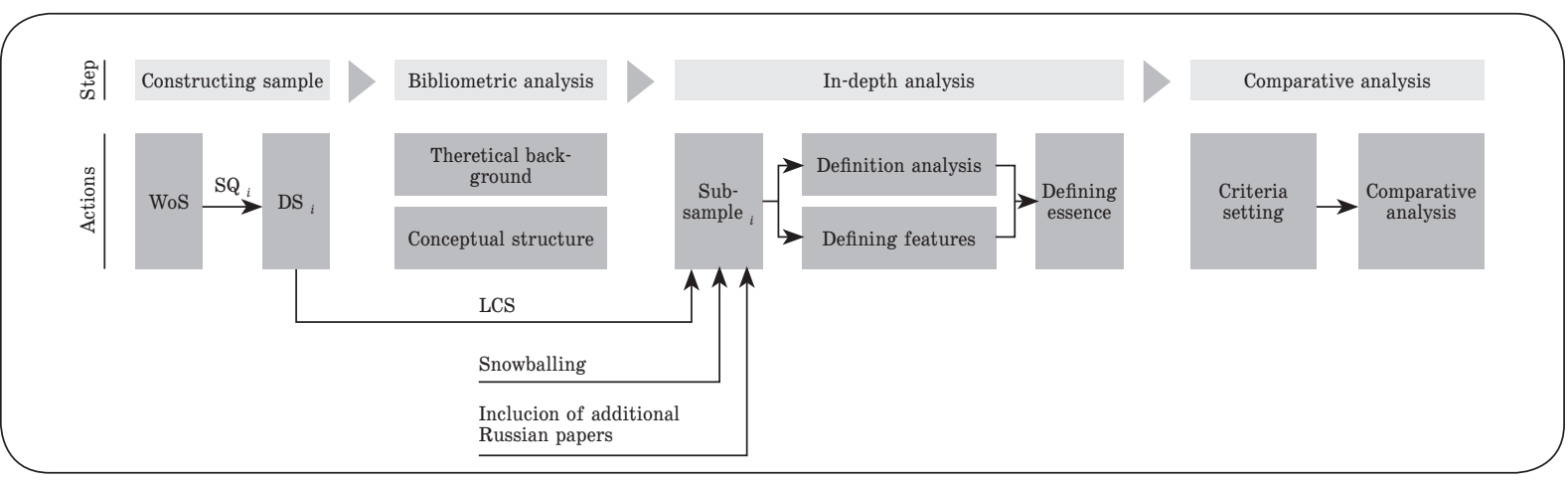

Fig. 1. Research design

N ot e: WoS - Web of Science database; $\mathrm{SQ}_{i}-$ search query, [1-3] (see Table 1); DS ${ }_{i}$ - dataset, [1-3] (see Table 1); LCS - local citation score; Sub-sample ${ }_{i}$ - samples of IE, BE and EE papers respectively, used for in-depth analysis.

references and not necessarily in the title of the article or as authors' keywords [Garfield, 1990; Garfield, Sher, 1993; Zhang, Huo, Liang, 2008]. Keywords plus allow us to construct an ontological connection with the existing managerial research field and capture the content of a paper with a greater depth and variety [Garfield, 1990].

(3) Titles of papers (10 most frequently used), which were provided more for illustrative purposes and outline various terms, which authors used to call their papers (as we will see they do not always correspond to the content). Thickness of the lines in Figures 2, 4 and 6 represents the level of connectedness among entities.

The next step in the bibliometric analysis (task 2) included research of a conceptual structure of the investigated research domain via the construction of a co-occurrence network. We used authors' keywords as a basis, which provide good representation of the content of the paper. It also allows constructing a semantic map of the studied field [Zupic, Cater, 2015], which can also be used to outline linkages among various subjects within it [He, 1998].This enabled us to take into account positioning of the concept employed by the authors of the analyzed papers. We applied a mixed Sequential Explanatory Approach [Creswell, 2009] and started with a conceptual net- work, which wouquld allow us to identify thematic networks of the studied domains (Figures 3, 5 and 7) and which then was followed up with the in-depth analysis. Proximity between words on the co-occurrence network corresponds to shared substance: when words are close to each other it means that a large portion of papers treat them together and vice versa. Centrality of the item represents its importance within the entire research domain, while density can be treated as a measure of the development of a particular theme [Cobo et al., 2011].

The second stage of the research included the in-depth analysis of the sample of papers, devoted to a particular research stream. To construct the sample from the initial dataset used for conducting the bibliometric analysis, we applied a mixed approach, which assessed both relevance of the paper within the research domain as well as its influence. When conducting the in-depth analysis of the selected papers, we started by reviewing their abstracts in order to obtain a preliminary understanding of the overall focus of these works. Then, we deeply analyzed the full text of these papers employing a concept-centric approach paying attention to the conceptualized understanding of what the IE, BE and EE concepts are. We used both our own judgement (basing upon the arguments made by 
Description of the samples for biliometric analysis

\begin{tabular}{|c|c|c|c|c|c|c|}
\hline $\mathbf{S Q}$ & Dataset & $\begin{array}{l}\text { Topic (search } \\
\text { query) }\end{array}$ & WoS Categories & Document Type & Timespan & $\begin{array}{c}\text { Number of } \\
\text { Studies }\end{array}$ \\
\hline 1 & DS_1 & $\begin{array}{l}\text { "innov* } \\
\text { ecosyst*" }\end{array}$ & $\begin{array}{c}\text { Management; } \\
\text { Business }\end{array}$ & $\begin{array}{l}\text { Article; } \\
\text { Review }\end{array}$ & All years & 266 \\
\hline 2 & DS_2 & $\begin{array}{l}\text { "busines* } \\
\text { ecosyst*" }\end{array}$ & $\begin{array}{c}\text { Management; } \\
\text { Business }\end{array}$ & $\begin{array}{l}\text { Article; } \\
\text { Review }\end{array}$ & All years & 213 \\
\hline 3 & DS_3 & $\begin{array}{c}\text { "entrepreneur* } \\
\text { ecosyst*" }\end{array}$ & $\begin{array}{c}\text { Management; } \\
\text { Business }\end{array}$ & $\begin{array}{l}\text { Article; } \\
\text { Review }\end{array}$ & All years & 298 \\
\hline
\end{tabular}

N ot e: final versions of the samples were retrieved in January 2020.

the authors of the analyzed papers) and the authors' personal indication of the essence of the studied concepts. When analyzing the essence of the IE, BE and EE concepts we extracted the definitions provided by the authors of the selected papers and distilled key features, which were applied within each of the study. To analyze ontological similarities and differences among these three concepts we first outlined a set of descriptors used by authors to describe the essence of the concepts. We then carefully coded these descriptors, checked the obtained list for consistency and used it as a basis for conducting a comparative analysis.

While analyzing the papers we first devote our attention to the provided definition of the studied concepts and then proceed with extracting their distinctive features. Figure 1 provides a description of the conducted literature review.

The in-depth analysis also included Russian papers on the notion of innovation ecosystem, business ecosystem and entrepreneurial ecosystem. We based our analysis upon the papers from a top-tier management journal according to the e-library database.

\section{Data}

The bibliometric database was extracted from ISI Web of Science database (WoS), as it in- cludes a comprehensive set of publications on the topic as well as all the necessary metadata of the studied publications: authors, titles, document sources, document type, authors' keywords, keywords plus, abstract, authors' affiliations, total citations, publication year, DOI, subject category, journal impact factor. This data is essential for carrying out the bibliometric analysis [Gomes et al., 2018]. Moreover, as it was indicated in [Ball, Tunger, 2006], WoS has a higher number of journals and papers of high quality. And finally, according to [Hicks, Wang, 2011] WoS and Scopus coverage greatly overlaps so that former can be taken as a major database for this research.

Due to the specific nature of our research aims, we applied different search criteria in each particular case. We ran three separate search queries on the following topics: "Innovation Ecosystem", "Business Ecosystem", and "Entrepreneurial Ecosystem" (for more details see Table 1).

For the search query we limited the scope of WoS categories to "Management" and "Business". We aimed to construct the most representative sample in the managerial field. Such a broad search query make it possible to collect the broadest scope of papers, which would allow us to construct an unbiased representation of the essence of the explored concepts. For the document types we chose 
"Article" and "Review" as these types of documents are peer-reviewed and have the most complete array of necessary meta-data.

For the purpose of performing the indepth analysis, we ranked the papers by value of their local citation score (LCS), which allowed us to outline the most relevant papers within the given research stream. For the purpose of the study, the sample of papers for the in-depth analysis should include those ones which account for at least half of all local citations (similarly to [Gomes et al., 2018]). Therefore, the threshold was determined to be at the level of $\leq 15$. This allowed us to form samples that included papers, which account for the majority of citations - namely $62,62.81$ and $54.12 \%$ for the IE, $\mathrm{BE}$ and EE concepts respectively. We then carefully examined abstracts of the papers that suited the LCS criteria and if they were relevant, they were included them in the sample for analysis. Snowballing of the papers from the samples allowed us to widen the scope of the analysis and incorporate a few papers, which were initially omitted but proved to be important for the purpose of the study. These papers are analyzed in the following section of the study.

For the Russian papers we used the E-Library database and retrieved peer-reviewed papers, which also complied with the Russian equivalents of the abovementioned topics: "innovat* ecosyst*", "business* ecosyst*", and "entrepreneur* ecosyst*". We started with the list of top-tier management journals according to the E-Library database basing upon the Science Index criteria. We then manually searched the websites of the top-10 journals on the abovementioned topics: "Voprosy Ekonomiki", "Foresight", "Russian Management Journal", "Higher School of Economics Economic Journal”, “The Journal of the New Economic Association", "Economic Policy", "Vestnik of Saint Petersburg University. Management", "Economics of Contemporary Russia", "ECO", and "Vestnik of Moscow University. Series 6: Economics". This allowed us to extract a number of relevant papers. The overall process was done manually due to the fact that the ecosystem research in Russian management literature is less popular and, therefore, much smaller number of papers exists. After that we read abstracts of all the extracted papers and in case if they fitted the topic of this research we proceed with the in-depth analysis.

This process resulted in the creation of three paper samples for the in-depth analysis of the following size: 13 papers for the IE concept, 8 papers for the BE concept and 11 papers for the EE concept. This size of the samples proved to be appropriate as it allowed us to reach saturation in terms of understanding the studied concepts. The indepth analysis of these papers will be provided in the corresponding parts of the following sections of the paper.

\section{Results}

This section of the paper will provide major results of the conducted investigation. We will start with the analysis of the essence of the IE, BE and EE concepts, define their connections to the well-established theoretical categories, analyze definitions and outline distinctive features. Then we will proceed with the comparative analysis, which will allow us to define similarities among these concepts and to demarcate them based upon their internal logic.

\section{Essence of innovation ecosystem concept}

Taking into account the existing pluralism of meanings regarding the essence of the IE phenomenon, we should first outline the existing connections to the well-established managerial categories (or, put it another way - knowledge fields) - Figure 2 .

It is worth noting that figure 2 includes two variations of the studied IE concept single and plural. However, they are rather similar in terms of their connections with the established managerial categories; therefore, they will be further treated together. As we can see, the most prominent connection of the IE notion is established with the 


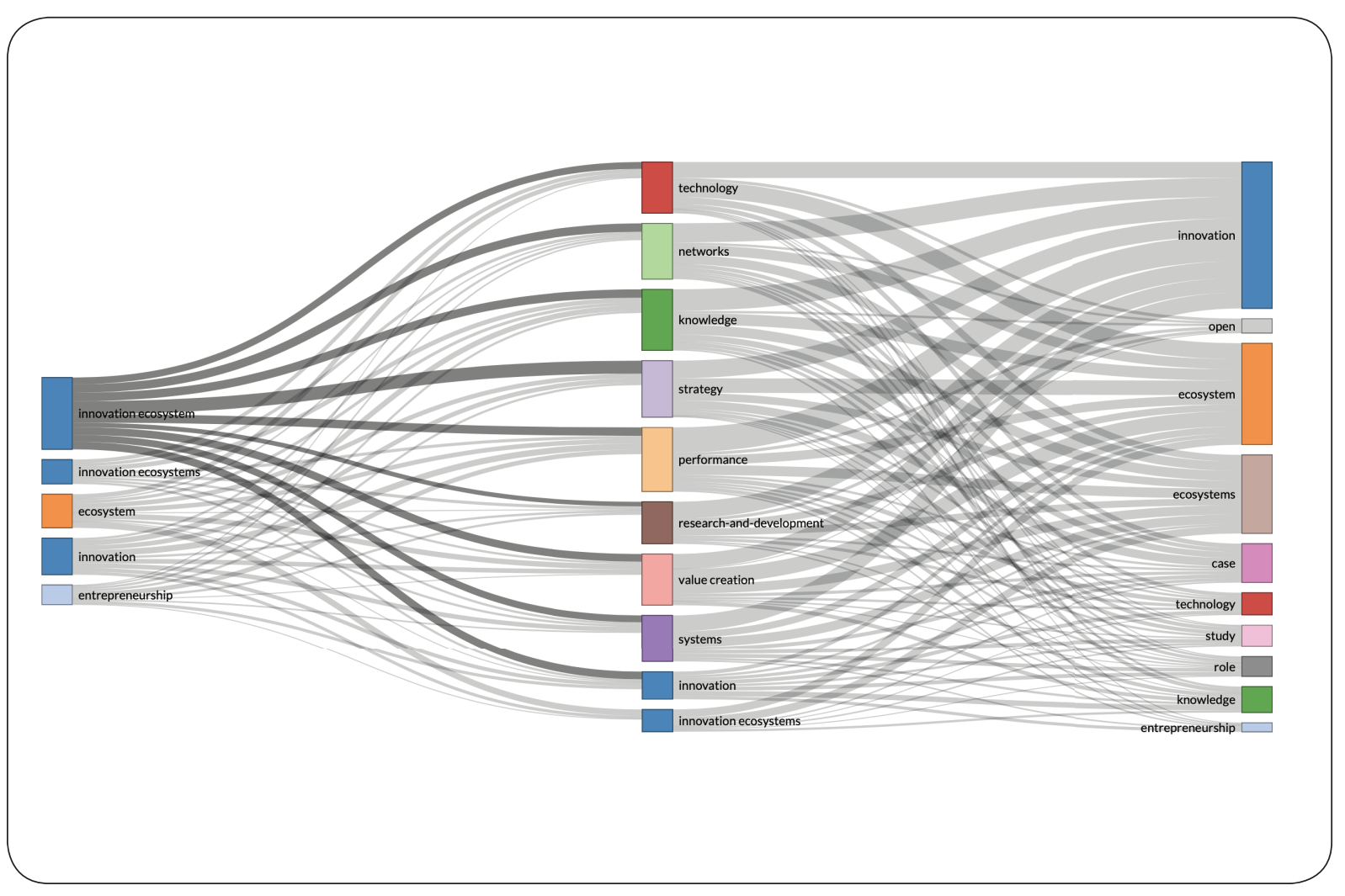

Fig. 2. Three-fields plot for the DS_1 dataset

N o t e: colors are automatically assigned by the software for convenience and do not have internal meaning. Readers of the printed issue are invited to visit the Russian Management Journal web-site for colored versions of the figures. - From the editors.

concept of strategy, which is not a big surprise as the vast majority of IE research (e.g. [Adner, 2006; 2017; Adner, Kapoor, $2010 ; 2016])$ is positioned and based upon the strategic management literature. This means that further in-depth analysis should be done with respect to those ones from this sphere. Another strong connection of the IE concept is established with the following categories: (1) knowledge; (2) performance; (3) networks; (4) value creation; and (5) systems. This allows us to imply the following. First, innovation ecosystem is a specific form of collaboration, which is based upon a certain amount of common resources (called "commons" in [Fjeldstad et al., 2012]) knowledge in this case - which allow economic agents to leverage them for their own purpose. Second, performance issues take an important place in the process of interfirm collaboration, as they ultimately define the purpose of such collaboration - creation of value that is impossible to produce by efforts of any single firm [Adner, 2006; Adner, Kapoor, 2010]. Third, IE is to a certain extent similar in its structure to the network, which as well includes a number of economic agents. However, there are two features that distinguish innovation ecosystem from a network: membership is not fixed (constellation of participants may vary over time); relations are not guided by formal rules. Forth, the major reason for IE participants to collaborate is the creation of a particular value proposition (VP), which was described above. And finally, IE adopts 


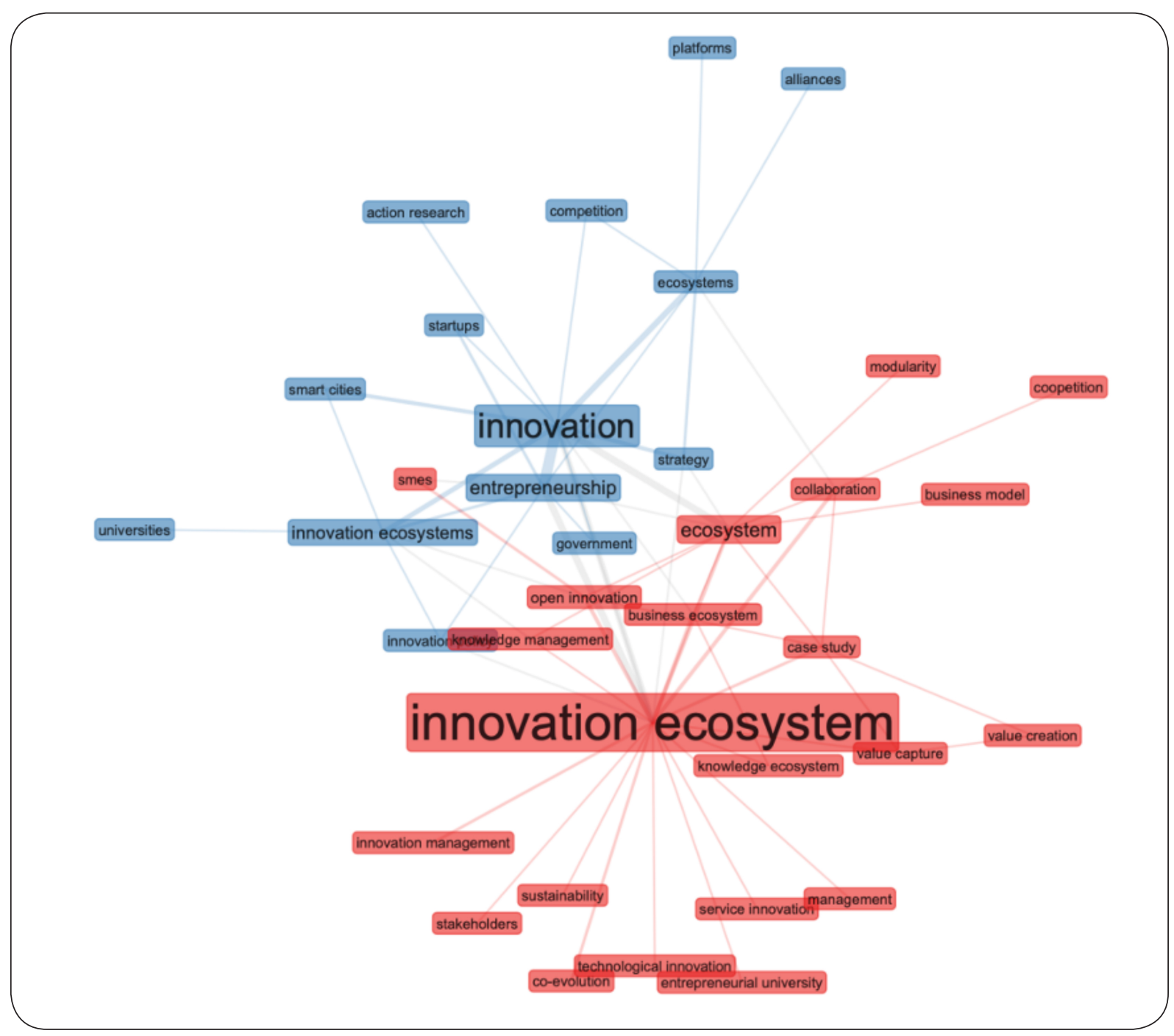

Fig. 3. Co-occurrence network for DS_1 dataset

several aspects of the system concept including interdependence [Adner, Kapoor, 2010], non-linearity of collaboration and existence of network effects [Jacobides, Cennamo, Gawer, 2018].

Next, we proceed with the construction of a co-occurrence network, which would allow us to explore the conceptual structure of the investigated research domain (Figure 3).

As we can see from the figure, the research domain was divided into two clusters: the one highlighted in blue was devoted to a more generalized notion of in- novation while the other highlighted in red was related to IE in particular. For the purpose of our research the second cluster is of particular interest. The most prominent is the fact that notions of IE, value capture and value creation are situated very close to each other, which contributes to their semantic proximity. Also, we can observe strong connection of IE with "collaboration" as well as with the notion of "co-evolution". This gives us the ground for a preliminary description of the underlying logic of innovation ecosystem construct. We may also 
Table 2

Analysis of IE stream papers

\begin{tabular}{|c|c|c|c|c|c|c|}
\hline № & Author & Journal & LCS & LC, \% & Definition & Key features \\
\hline 1 & $\begin{array}{l}\text { [Adner, } \\
\text { Kapoor, } \\
2010]\end{array}$ & $\begin{array}{l}\text { Strategic } \\
\text { Management } \\
\text { Journal }\end{array}$ & 90 & 18.79 & $\begin{array}{l}\text { “...Suppliers serve as } \\
\text { inputs to focal actor [...] } \\
\text { focal actors' product } \\
\text { serves as an input to its } \\
\text { customer [...] may also } \\
\text { need to bundle it with [...] } \\
\text { complements..." }\end{array}$ & $\begin{array}{l}\text { Explicit interdependence } \\
\text { of participants; Location } \\
\text { of actors interferes with } \\
\text { the creation and capture } \\
\text { of value; Importance of } \\
\text { complementarities }\end{array}$ \\
\hline 2 & $\begin{array}{l}\text { [Adner, } \\
2006]\end{array}$ & $\begin{array}{l}\text { Harvard } \\
\text { Business } \\
\text { Review }\end{array}$ & 66 & 13.78 & $\begin{array}{l}\text { "The collaborative ar- } \\
\text { rangements through which } \\
\text { firms combine their } \\
\text { individual offerings into a } \\
\text { coherent, customer-facing } \\
\text { solution" }\end{array}$ & $\begin{array}{l}\text { Complex nature of VP, } \\
\text { which is created by the } \\
\text { means of collective } \\
\text { efforts; New set of risks } \\
\text { which are to a great } \\
\text { extent determined by } \\
\text { possible delays faced by } \\
\text { producers of } \\
\text { complementary offerings; } \\
\text { Iterative strategy making } \\
\text { process; Existence of } \\
\text { leading entity }\end{array}$ \\
\hline 3 & $\begin{array}{l}\text { [Adner, } \\
\text { Kapoor, } \\
2016]\end{array}$ & $\begin{array}{l}\text { Strategic } \\
\text { Management } \\
\text { Journal }\end{array}$ & 25 & 5.22 & $\begin{array}{l}\text { Rely on papers by [Adner, } \\
\text { 2006; Adner, Kapoor, } \\
\text { 2010; Christensen, } \\
\text { Rosenbloom, 1995; Iansiti, } \\
\text { Levien, 2004; Moore, } \\
\text { 1993] }\end{array}$ & $\begin{array}{l}\text { Homogeneity of actions } \\
\text { performed by } \\
\text { heterogeneous actors; } \\
\text { Components of the } \\
\text { ecosystem should be } \\
\text { balanced }\end{array}$ \\
\hline 4 & $\begin{array}{l}\text { [Adner, } \\
\text { 2017] }\end{array}$ & $\begin{array}{l}\text { Journal of } \\
\text { Management }\end{array}$ & 24 & 5.01 & $\begin{array}{l}\text { Investigates a broader } \\
\text { concept of ecosystem }\end{array}$ & $\begin{array}{l}\text { Alignment of positions } \\
\text { and activities of } \\
\text { participants; } \\
\text { Manifoldness; Joint value } \\
\text { creation as a goal }\end{array}$ \\
\hline 5 & $\begin{array}{l}\text { [Carayannis, } \\
\text { Campbell, } \\
2009]\end{array}$ & $\begin{array}{l}\text { International } \\
\text { Journal of } \\
\text { Technology } \\
\text { Management }\end{array}$ & 20 & 4.18 & $\begin{array}{l}\text { “...Multi-level, multi-mod- } \\
\text { el, multi-nodal and } \\
\text { multi-agent system of } \\
\text { systems [...] consists of } \\
\text { innovation meta-networks } \\
\text { [...] knowledge meta-clus- } \\
\text { ters [...], which in turn } \\
\text { constitute agglomeration } \\
\text { of human, social, intellec- } \\
\text { tual and financial capital } \\
\text { stocks and flows as well as } \\
\text { cultural and technological } \\
\text { artifacts and modalities, } \\
\text { continually co-evolving, } \\
\text { co-specializing and } \\
\text { co-opeting” }\end{array}$ & $\begin{array}{l}\text { Diversity of actors; } \\
\text { Arrangement along } \\
\text { heterogeneous innovation } \\
\text { networks and knowledge } \\
\text { clusters; Non-linearity } \\
\text { of collaboration; } \\
\text { Co-specialization; } \\
\text { Co-opetition }\end{array}$ \\
\hline
\end{tabular}


Table 2 (end)

\begin{tabular}{|c|c|c|c|c|c|c|}
\hline № & Author & Journal & LCS & LC, \% & Definition & Key features \\
\hline 6 & $\begin{array}{l}\text { [Nambisan, } \\
\text { Baron, } \\
\text { 2013] }\end{array}$ & $\begin{array}{l}\text { Entrepre- } \\
\text { neurship } \\
\text { Theory and } \\
\text { Practice }\end{array}$ & 20 & 4.18 & $\begin{array}{l}\text { Relies upon the definition } \\
\text { provided in paper by } \\
\text { [Moore, 1993] }\end{array}$ & $\begin{array}{l}\text { Treats IE and BE } \\
\text { synonymously; } \\
\text { Interdependence of } \\
\text { participants; Common set } \\
\text { of goals and objectives; } \\
\text { Shared set of knowledge } \\
\text { and skills }\end{array}$ \\
\hline 7 & $\begin{array}{l}\text { [Ritala et } \\
\text { al., 2013] }\end{array}$ & $\begin{array}{l}\text { International } \\
\text { Journal of } \\
\text { Technology } \\
\text { Management }\end{array}$ & 18 & 3.76 & $\begin{array}{l}\text { “...A business ecosystem, } \\
\text { which aims at creating } \\
\text { and capturing value from } \\
\text { innovation activities...” }\end{array}$ & $\begin{array}{l}\text { Existence of leading } \\
\text { entity; Simultaneous } \\
\text { collaboration and } \\
\text { competition; Collaborative } \\
\text { value creation; Individual } \\
\text { value capture }\end{array}$ \\
\hline 8 & $\begin{array}{l}\text { [Oh et al., } \\
2016]\end{array}$ & Technovation & 18 & 3.76 & $\begin{array}{l}\text { No explicit definition is } \\
\text { provided }\end{array}$ & $\begin{array}{l}\text { Comprises research and } \\
\text { commercial economy }\end{array}$ \\
\hline 9 & $\begin{array}{l}\text { [Rohrbeck, } \\
\text { Holzle, } \\
\text { Gemunden, } \\
2009]\end{array}$ & $\begin{array}{l}\text { R\&D } \\
\text { Management }\end{array}$ & 16 & 3.34 & $\begin{array}{l}\text { Relies upon the definition } \\
\text { provided in paper by } \\
\text { [Moore, 1993] }\end{array}$ & $\begin{array}{l}\text { Treats IE and BE } \\
\text { synonymously; Existence } \\
\text { of leading entity; } \\
\text { Collaborative creation of } \\
\text { innovations }\end{array}$ \\
\hline 10 & $\begin{array}{l}\text { [Brusoni, } \\
\text { Precipe, } \\
\text { 2013]* }\end{array}$ & $\begin{array}{l}\text { Advances in } \\
\text { Strategic } \\
\text { Management }\end{array}$ & 8 & 1.67 & $\begin{array}{l}\text { Relies upon the definition } \\
\text { provided in paper by } \\
\text { [Moore, 1993] }\end{array}$ & $\begin{array}{l}\text { Focal entity both frames } \\
\text { and solves the problems; } \\
\text { Focal entity arranges and } \\
\text { generates knowledge to } \\
\text { promote innovation and } \\
\text { capture its value }\end{array}$ \\
\hline 11 & $\begin{array}{l}\text { [Jacobides, } \\
\text { Cennamo, } \\
\text { Gawer, } \\
2018]^{*}\end{array}$ & $\begin{array}{l}\text { Strategic } \\
\text { Management } \\
\text { Journal }\end{array}$ & 8 & 1.67 & $\begin{array}{l}\text { Relies upon the definition } \\
\text { provided in paper by } \\
\text { [Adner, 2006] }\end{array}$ & $\begin{array}{l}\text { Focal firm may not even } \\
\text { be directly connected to } \\
\text { its complementors; Focal } \\
\text { innovation and the set of } \\
\text { components and } \\
\text { complements that support } \\
\text { it }\end{array}$ \\
\hline 12 & $\begin{array}{l}\text { [Ruker- } \\
\text { Shaeffer, } \\
\text { Fischer, } \\
\text { Queiroz, } \\
2018] * \%\end{array}$ & $\begin{array}{l}\text { Foresight and } \\
\text { STI } \\
\text { Governance }\end{array}$ & - & - & $\begin{array}{l}\text { Paper treats IE as a } \\
\text { synonym of regional } \\
\text { innovation system }\end{array}$ & - \\
\hline 13 & $\begin{array}{l}\text { [Beck, } \\
\text { Gadzhaeva, } \\
\text { 2018] ** }\end{array}$ & $\begin{array}{l}\text { Bulletin of } \\
\text { Moscow } \\
\text { University }\end{array}$ & - & - & $\begin{array}{l}\text { “...Collaborative value } \\
\text { creation and regulation of } \\
\text { collective value extrac- } \\
\text { tion...” }\end{array}$ & $\begin{array}{l}\text { Collective value creation; } \\
\text { Focal firm coordinates } \\
\text { activities within the } \\
\text { ecosystem }\end{array}$ \\
\hline
\end{tabular}

N ot es: * included as a result of snowballing process; ** included from the Russian papers sample. 
notice the presence of the knowledge related keywords, which support the abovementioned thesis of collective usage of "commons".

However, we should not rely solely on the results of this rather mechanistic process of investigation. That is why the abovementioned results will be taken as preliminary, which are further developed by virtue of an in-depth investigation of the papers from the dataset.

The sample of papers for investigating the essence of the IE concept included nine most locally cited papers, which together account for $62 \%$ of all the citations within the sample. The data also included two papers which were outlined during the application of the snowballing technique and are considered to be important: by [Brusoni, Precipe, 2013], which, despite having a moderate citation score provides important insights about the role of a focal actor within the ecosystem; and by [Jacobides, Cennamo, Gawer, 2018], which includes a vital description of the nature of a value proposition developed within the ecosystem.

For the purpose of the study we also analyzed two relevant Russian papers [Beck, Gadzhaeva, 2018; Ruker-Shaeffer, Fischer, Queiroz, 2018] devoted to the concept of innovation ecosystem. The analysis of the final sample of papers devoted to the notion of IE is provided in Table 2. The sample for the analysis of IE stream included only those papers, which after carefully reading their abstracts were considered to be devoted to the concept of innovation ecosystem. This resulted in the exclusion of a number of highly cited papers (e.g.: [Moore, 1993], which is devoted to a different concept of business ecosystem and will be analyzed in the corresponding section of the study) but allowed us to distill the meaning of the innovation ecosystem concept. Thus, we ended up with the sample of 13 papers.

The conducted analysis of the papers devoted to the IE phenomena allows us to conclude with the following explanations of the concept. First, we observed a general agreement among scholars on the fact that the ultimate reason for collaboration of economic agents is determined by the nature of a value proposition, which cannot be created by virtue of a single given firm. Second, the so-called focal actor is a central entity of this process and is responsible for coordinating activities of ecosystem participants. Third, the papers analyzed stress the fact that interdependence of economic agents is not determined by market or hierarchy mechanisms but is rather of voluntary nature. Fourth, members of the ecosystem may be both collaborating and competing with each other and this fact does not undermine the ecosystem existence but rather explains the absence of legal arrangements among them.

\section{Essence of business ecosystem concept}

The bibliometric analysis of the papers devoted to the research of $\mathrm{BE}$ concept was also started with the outline of the existing connections to the well-established managerial categories - Figure 4.

As we can see, Figure 4 includes two variations of the studied concept of business ecosystem (single and plural). At the same time, a brief analysis of their connections with the existing managerial categories allows us to argue in favour of their similarity. Therefore, during the analysis they will be treated together. The concept of business ecosystem demonstrates the most prominent connection with the notions of innovation and strategy. From our standpoint an explanation of this can be found in the nature of objects which were taken for investigation in the analyzed papers. Usually papers on $\mathrm{BE}$ pertain to the strategy stream of managerial literature and investigate a particular innovative VP (e.g.: [Clarysse et al., 2014; Gawer, Cusumano, 2014; Li, 2009; Teece, 2007]). We can also observe a strong connection to the concept of value creation both for end customer whose requirements determine the set of complementary offering that need to be delivered to him [Clarysse et al., 2014] and for the participants of the ecosystem [Clarysse et al., 2014; Kapoor, Lee, 2013]. A technological aspect of busi- 


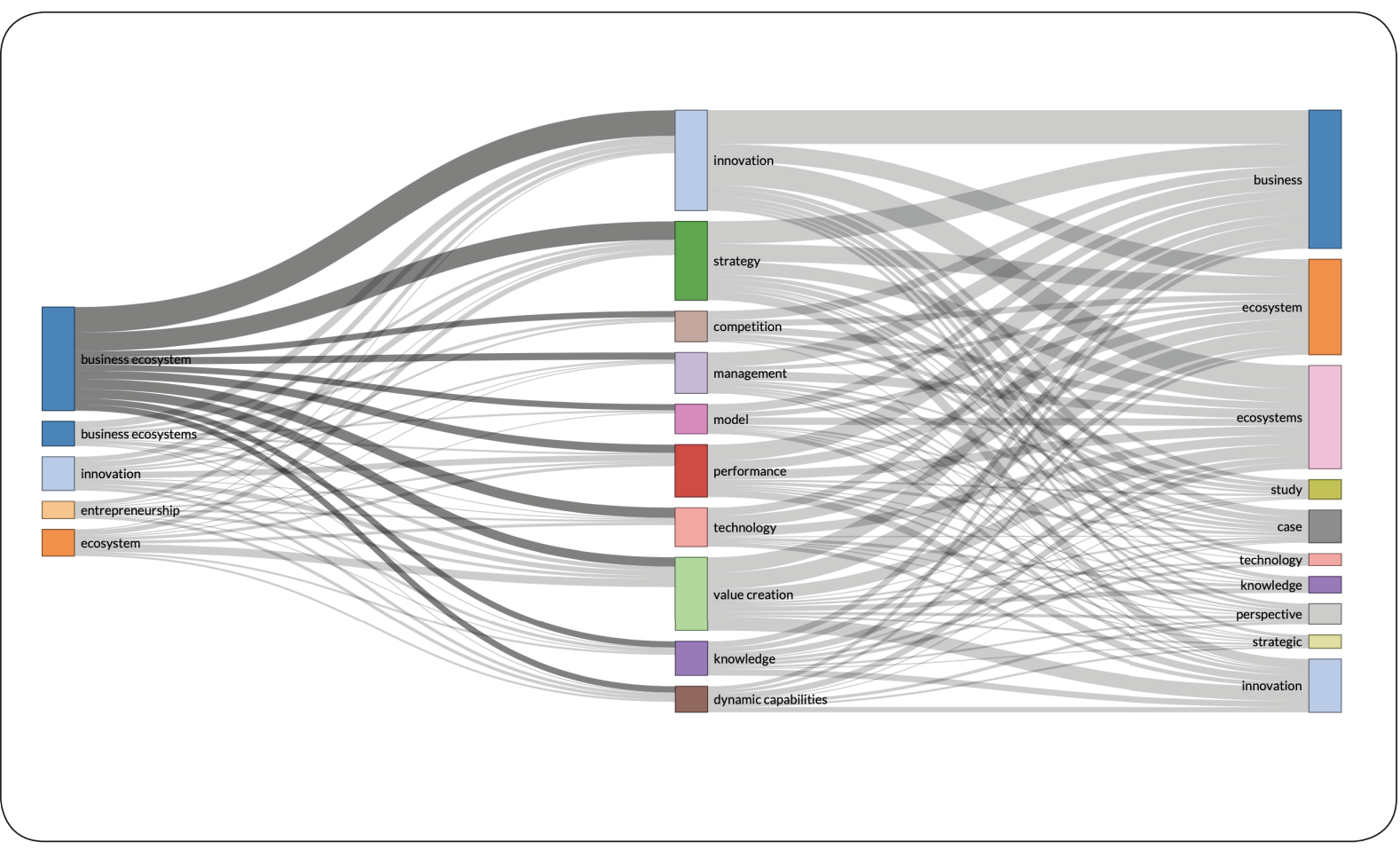

Fig. 4. Three-fields plot for the DS_2 dataset

ness ecosystem is determined by the fact that the $\mathrm{BE}$ research is usually concentrated on investigation of the ecosystem phenomenon, which emerged around a particular technological domain [Li, 2009] or platform [Gawer, Cusumano, 2014] acting as a catalyst of various spin-offs in a form of complementary offering by ecosystem participants. Performance explains the underlying logic of collaboration - when the ecosystem is more than just a sum of efforts of its participants. This means that actors consider the existing gains from participation and the overall ecosystem should be treated as an economic community where actors pursue certain yields.

Next, we proceed with the analysis of a conceptual structure of the BE research domain, which can be represented through the following co-occurrence network (Figure 5).

As we can see, the studied sample of papers devoted to investigation of the $\mathrm{BE}$ concept was divided into two major clusters of a medium density: (1) "business ecosystem"; and (2) "business ecosystems" (BEs) which just correspond to variation of the studied concept. However, the content of these clusters varies to a certain extent. The first one includes a strong connection of $\mathrm{BE}$ and notions of collaboration (which explains the internal logic of BE); complementors (which, as it was already mentioned, are extremely important); platform (which can serve as a core element of the business ecosystem); and network effects (determined by the nature of collaboration in BE). The second cluster represents a tight connection between the notions of BEs and entrepreneurship, innovation and strategy. These peculiarities necessitate further in-depth investigation of papers devoted to the business ecosystem concept with a special emphasis on its key features, which would allow us to understand the underlying logic of this notion.

The sample of papers for investigating the essence of the BE concept included eight 


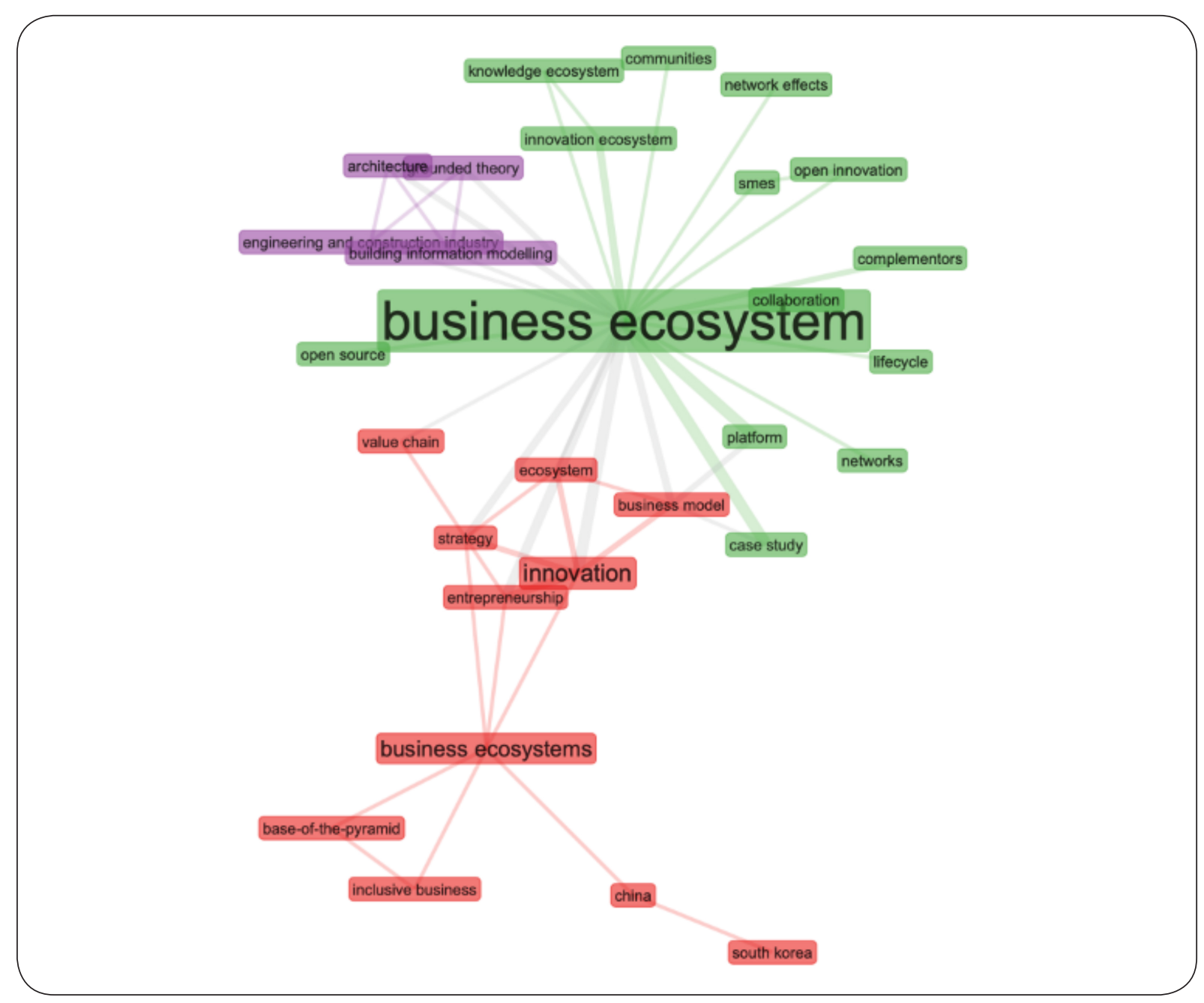

Fig. 5. Co-occurrence network for DS_2 dataset

most locally cited papers devoted to the concept of business ecosystem, which together account for $62.81 \%$ of all the citations within the sample (Table 3 ).

The conducted analysis of publication within the BE stream allows us to make a number of conclusions. First, the authors of the analyzed papers devote attention to the specific nature of collaboration among ecosystem participants - coopetition. Second, a focal actor - leading firm - is the overall orchestrator of the process and is responsible for the ecosystem survival. Third, the goal of collaboration is determined by the fact that participants are able to assess the existing common resources and knowledge and therefore deliver a complex VP to the customer. Fourth, collaborating within the ecosystem creates a specific form of interdependence (usually determined by a particular technology) with a corresponding set of risks. In particular, a focal value proposition becomes dependent on the ability of complementors to deliver their offerings to the customer.

Essence of entrepreneurial ecosystem concept

The bibliometric analysis of the EE concept was started with the outline of its existing 
Table 3

Analysis of BE stream papers

\begin{tabular}{|c|c|c|c|c|c|c|}
\hline № & Author & Journal & LCS & LC, \% & Definition & Key features \\
\hline 1 & $\begin{array}{l}\text { [Moore, } \\
\text { 1993] }\end{array}$ & \begin{tabular}{|l} 
Harvard \\
Business \\
Review
\end{tabular} & 88 & 16.70 & $\begin{array}{l}\text { "In a business ecosystem, } \\
\text { companies coevolve } \\
\text { capabilities around a new } \\
\text { innovation: they work } \\
\text { cooperatively and competi- } \\
\text { tively to support new } \\
\text { products, satisfy customer } \\
\text { needs, and eventually } \\
\text { incorporate the next round } \\
\text { of innovations" }\end{array}$ & $\begin{array}{l}\text { Simultaneous cooperation } \\
\text { and rivalry; Common } \\
\text { goal - delivery of value } \\
\text { to the customer; Existence } \\
\text { of a leader who coordi- } \\
\text { nates the development of } \\
\text { the ecosystem; Stability of } \\
\text { the structure of value- } \\
\text { added components and } \\
\text { processes; Presence of } \\
\text { wide variety of members; } \\
\text { Distribution of roles; } \\
\text { Ecosystem coordination } \\
\text { mechanisms }\end{array}$ \\
\hline 2 & $\begin{array}{l}\text { [Adner, } \\
\text { Kapoor, } \\
\text { 2010] * }\end{array}$ & $\begin{array}{l}\text { Strategic } \\
\text { Management } \\
\text { Journal }\end{array}$ & 62 & 11.76 & - & - \\
\hline 3 & $\begin{array}{l}\text { [Iansiti, } \\
\text { Levien, } \\
2004]\end{array}$ & $\begin{array}{l}\text { Harvard } \\
\text { Business } \\
\text { Review }\end{array}$ & 52 & 9.87 & $\begin{array}{l}\text { “...Includes [...] companies } \\
\text { to which you outsource } \\
\text { business functions, } \\
\text { institutions that provide } \\
\text { you with financing, firms } \\
\text { that provide the technol- } \\
\text { ogy needed to carry on } \\
\text { your business, and makers } \\
\text { of complementary prod- } \\
\text { ucts that are used in } \\
\text { conjunction with your } \\
\text { own” }\end{array}$ & $\begin{array}{l}\text { Multi-agent set of } \\
\text { participants; } \\
\text { Complementors are } \\
\text { important; Loose } \\
\text { interconnectedness of the } \\
\text { participants; Presence of a } \\
\text { certain key element - } \\
\text { hubs, which regulate } \\
\text { ecosystem health; } \\
\text { Constant change of inputs; } \\
\text { Meaningful diversity } \\
\text { through creation of } \\
\text { valuable new functions/ } \\
\text { niches; Shared resources } \\
\text { and/or assets; Extraction } \\
\text { and share of value by a } \\
\text { key player }\end{array}$ \\
\hline 4 & \begin{tabular}{|l} 
[Teece, \\
2007]
\end{tabular} & $\begin{array}{l}\text { Strategic } \\
\text { Management } \\
\text { Journal }\end{array}$ & 37 & 7.02 & $\begin{array}{l}\text { “...Community of organiza- } \\
\text { tions, institutions, and } \\
\text { individuals that impact } \\
\text { the enterprise and the } \\
\text { enterprise's customers and } \\
\text { suppliers" }\end{array}$ & $\begin{array}{l}\text { Multiplicity of actors } \\
\text { involved; Positioning of } \\
\text { actors within the } \\
\text { ecosystem }\end{array}$ \\
\hline 5 & $\begin{array}{l}\text { [Gawer, } \\
\text { Cusumano, } \\
\text { 2014] }\end{array}$ & $\begin{array}{l}\text { Journal of } \\
\text { Product } \\
\text { Innovation } \\
\text { Management }\end{array}$ & 28 & 5.31 & $\begin{array}{l}\text { Relies upon the definition } \\
\text { provided in the paper by } \\
\text { [Iansiti, Levien, 2004] }\end{array}$ & $\begin{array}{l}\text { Platform base; } \\
\text { Management of relations; } \\
\text { Co-evolution of platform } \\
\text { and ecosystem }\end{array}$ \\
\hline
\end{tabular}

PЖM 18 (1): 73-102 (2020) 
Table 3 (end)

\begin{tabular}{|c|c|c|c|c|c|c|}
\hline № & Author & Journal & LCS & LC, \% & Definition & Key features \\
\hline 6 & {$[\mathrm{Li}, 2009]$} & Technovation & 24 & 4.55 & $\begin{array}{l}\text { Relies upon the definition } \\
\text { provided in paper by } \\
\text { [Iansiti, Levien, 2004] }\end{array}$ & $\begin{array}{l}\text { Loose character of } \\
\text { interconnectedness; } \\
\text { Presence of a keystone } \\
\text { firm, which serves as a } \\
\text { certain catalyst of various } \\
\text { network effects; } \\
\text { "Cooperational" value of } \\
\text { participants - value of } \\
\text { the ecosystem exceeds the } \\
\text { sum of individual values } \\
\text { of firms }\end{array}$ \\
\hline 7 & $\begin{array}{l}\text { [Kapoor, } \\
\text { Lee, 2013] }\end{array}$ & $\begin{array}{l}\text { Strategic } \\
\text { Management } \\
\text { Journal }\end{array}$ & 20 & 3.80 & $\begin{array}{l}\text { “...Interdependent activi- } \\
\text { ties carried out by [...] } \\
\text { customers, complementors } \\
\text { and suppliers" }\end{array}$ & $\begin{array}{l}\text { (Technological) } \\
\text { interdependencies among } \\
\text { participants; Focus on } \\
\text { appropriability of returns; } \\
\text { Complementary activities }\end{array}$ \\
\hline 8 & $\begin{array}{l}\text { [Clarysse et } \\
\text { al., 2014] }\end{array}$ & $\begin{array}{l}\text { Research } \\
\text { Policy }\end{array}$ & 20 & 3.80 & $\begin{array}{l}\text { “...Interorganizational } \\
\text { networks...” [which] } \\
\text { “...consist of both collabo- } \\
\text { rative and competitive } \\
\text { relationships...” }\end{array}$ & $\begin{array}{l}\text { Co-evolution of roles and } \\
\text { capabilities of } \\
\text { participants; Alignment } \\
\text { according to the direction } \\
\text { set by central } \\
\text { company(ies); Loose } \\
\text { interconnectedness; } \\
\text { Interdependence of } \\
\text { participants in terms of } \\
\text { their mutual performance; } \\
\text { Presence of a "keystone" } \\
\text { company }\end{array}$ \\
\hline
\end{tabular}

Notes: * paper is devoted to IE concept (BE is provided only in the keywords section), therefore it is excluded from in-depth analysis in this section; no Russian papers in top-tier journals were found.

connections to the well-established managerial categories - Figure 6 .

As we can see, Figure 6 includes two variations of the studied EE concept (single and plural definitions). However, due to their similarity in terms of connections they will be further treated together. First of all, we should stress that the EE concept has the most prominent connections with the following knowledge domains: (1) innovation; (2) knowledge; (3) growth; (4) policy; (5) performance. As for innovation, such a connection seems to be self-exploratory as entrepreneurship in its nature includes the creation of something new or recombination of the existing. The presence of the knowledge concept in the figure explains the underlying foundation of entrepreneurial ecosystem existence (it will be described in detail further) - entrepreneurs are keen to share their knowledge with each other, thereby creating a positive feedback loop and stimulating the growth of the overall ecosystem [Brown, Mason, 2017]. The notion of growth is related to the entrepreneurs and the ecosystem both of which are interrelated in terms of their survival and development. And finally, performance issues are prominent in the EE research as 


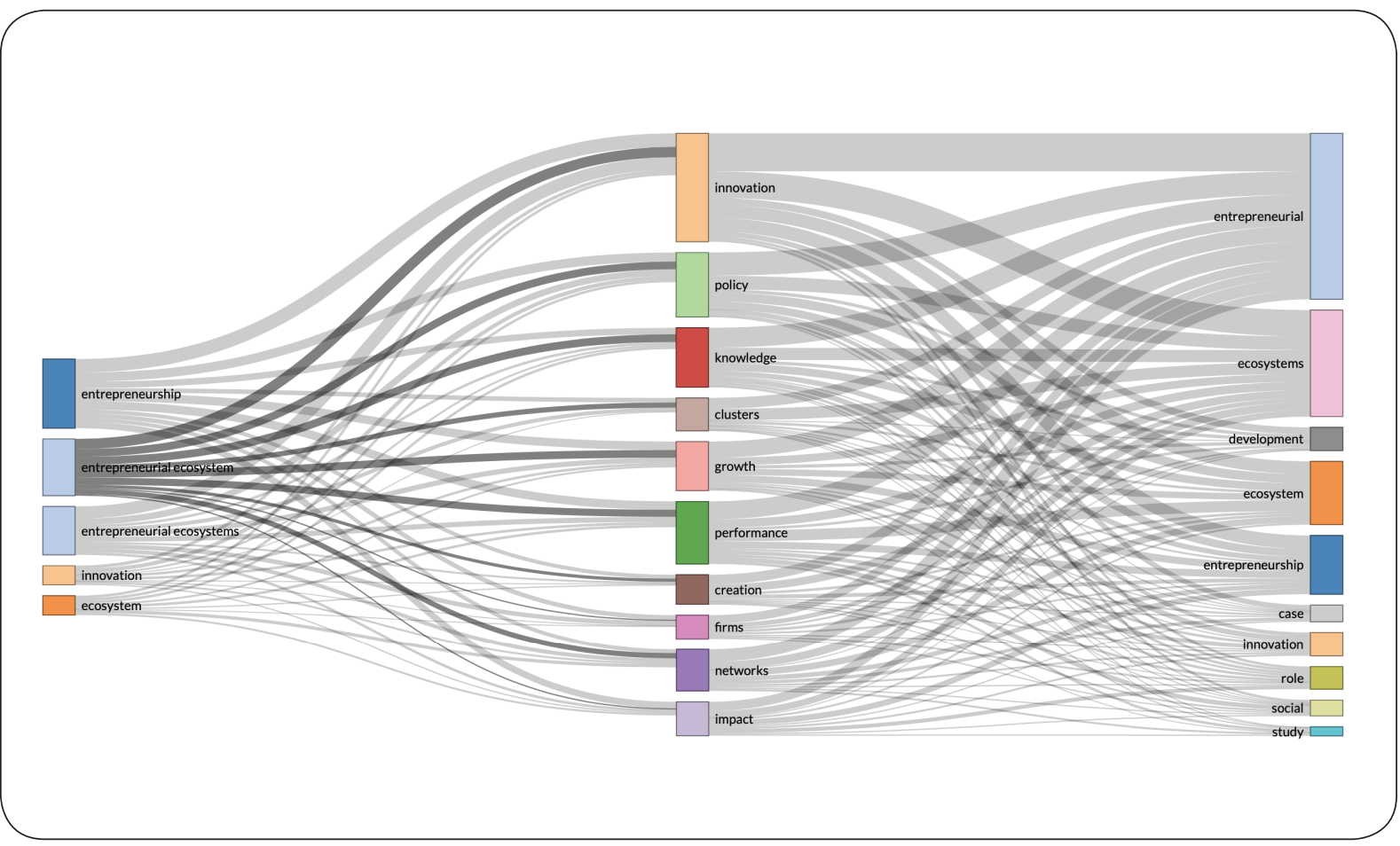

Fig. 6. Three-fields plot for the DS_3 dataset

well. Just as in case of IE and BE, members of the ecosystem pursue an ultimate goal to leverage the existing possibilities for their own good, which can be treated in terms of performance.

Further investigation of the EE phenomenon included the construction of a co-occurrence network (Figure 7), which would provide us with the preliminary understanding of the conceptual structure of this research domain.

As we can see from the figure, the analysis revealed three clusters. The first one provides a structure of knowledge on a broader concept of entrepreneurship and is prominent in this dataset as papers on EE heavily rely upon this stream of literature. Existence of the other two is explained by the existing fragmentation of the research field and a variety of studies on both the concept itself and its various implementations (case studies). Further analysis will be devoted to the latter two clusters. If we take a closer look at Figure 7, we may argue that the concept of entrepreneurial ecosystem is concerned about the creation of new ventures. It is strongly related to the regional development and draws a particular attention to the relational aspect of collaboration and is focused on innovation.

This gives us a strong foundation for conducting an in-depth analysis of the papers from this stream of research. The sample of articles for investigating the essence of the EE concept included 8 most locally cited papers, which together account for $54.12 \%$ of all the citations within the sample as well as three relevant Russian papers [Chepurenko, 2019; Solesvik, Westhead, 2019; Trabskaja, Mets, 2019]. All the papers provided in the table are solely concentrated upon the notion of entrepreneurial ecosystem and will allow us to come up with a set of features that distinguish it from other types of ecosystems. The analysis of the papers from the sample is provided in the Table 


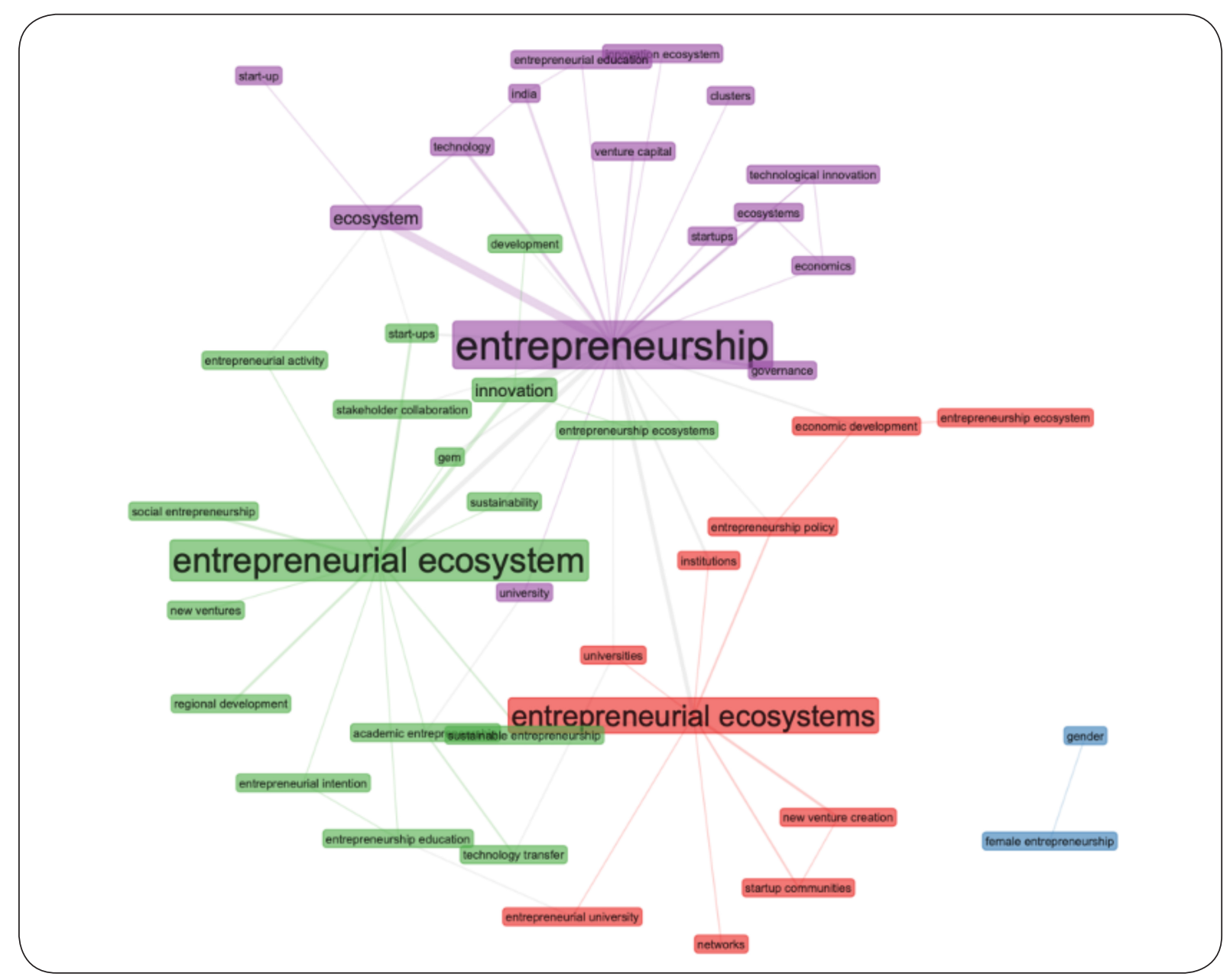

Fig. 7. Co-occurrence network for DS_3 dataset

4. It is also worth noting that the EE sample included only those papers, which included the "ecosystem" keyword. Therefore, we deliberately did not include studies on clusters as they provide a different lens for analysis and do not explicitly consider ecosystem-specific interfirm collaborations [Spigel, Harrison, 2018].

The conducted analysis of publications devoted to the investigation of the EE phenomenon allows us to argue the following. First, the overall goal of entrepreneurial ecosystem existence is the creation and development of new ventures. Second, collaboration of ecosystem participants is spatially bounded due to the specificity of common resources - corresponding infrastructure, which cannot be easily transferred to another geographical area; and shared knowledge, which is usually not formalized and, therefore, has a limited ability of being shared through big distances. Third, entrepreneurial ecosystem is based upon the simultaneous existence of two value types: common (the value of the ecosystem), which is created by collective efforts of participants; and individual, which is created on a firm-base level. The latter cannot be extracted by anyone else and is a result of the collective efforts of the ecosystem members.

The conducted analysis of the papers devoted to investigation of innovation, busi- 
Analysis of EE stream papers

\begin{tabular}{|c|c|c|c|c|c|c|}
\hline № & Author & Journal & LCS & LC, \% & Definition & Key features \\
\hline 1 & \begin{tabular}{|l} 
[Spigel, \\
$2017]$
\end{tabular} & $\begin{array}{l}\text { Entrepre- } \\
\text { neurship } \\
\text { Theory and } \\
\text { Practice }\end{array}$ & 72 & 15.22 & $\begin{array}{l}\text { "Entrepreneurial ecosys- } \\
\text { tems are combinations of } \\
\text { social, economic, and } \\
\text { cultural elements within a } \\
\text { region, which support the } \\
\text { development and growth } \\
\text { of innovative startups and } \\
\text { encourage nascent entre- } \\
\text { preneurs and other actors } \\
\text { to take the risks of } \\
\text { starting, funding and } \\
\text { otherwise assisting } \\
\text { high-risk ventures" }\end{array}$ & $\begin{array}{l}\text { Spatial constraint of EE; } \\
\text { EE incorporates a rela- } \\
\text { tional governance without } \\
\text { clear power hierarchy or } \\
\text { formalized enforcement } \\
\text { methods; Participants usu } \\
\text { ally share (core) } \\
\text { technology(ies) and } \\
\text { exchange knowledge - } \\
\text { about challenges of } \\
\text { developing a venture in } \\
\text { particular }\end{array}$ \\
\hline 2 & $\begin{array}{l}\text { [Autio et } \\
\text { al., 2014] }\end{array}$ & $\begin{array}{l}\text { Research } \\
\text { Policy }\end{array}$ & 43 & 9.09 & $\begin{array}{l}\text { Paper relies upon the } \\
\text { notion of multiplicity of } \\
\text { entrepreneurial ecosystems } \\
\text { in the process of entrepre- } \\
\text { neurial innovation } \\
\text { [Isenberg, 2010] and argue } \\
\text { that "entrepreneurial } \\
\text { ecosystems regulate the } \\
\text { direction and quality of } \\
\text { entrepreneurial innovation } \\
\text { by shaping the direction } \\
\text { and potential rewards of } \\
\text { alternative courses of } \\
\text { technological develop- } \\
\text { ment..." [Autioet al., } \\
\text { 2014, p. 1100] }\end{array}$ & $\begin{array}{l}\text { Evolving nature of the } \\
\text { phenomenon; Focus on } \\
\text { creation of new ventures; } \\
\text { Spatial constraint of EE }\end{array}$ \\
\hline 3 & $\begin{array}{l}\text { [Acs et al., } \\
2017]\end{array}$ & $\begin{array}{l}\text { Small Business } \\
\text { Economics }\end{array}$ & 28 & 5.92 & $\begin{array}{l}\text { “...Entrepreneurial ecosys- } \\
\text { tem approach [...] empha- } \\
\text { sizes the interdependence } \\
\text { between actors and factors } \\
\text { but sees entrepreneurship } \\
\text { (new value creation by } \\
\text { agents) as the output...” }\end{array}$ & $\begin{array}{l}\text { Both entrepreneurs and } \\
\text { firms may serve as an } \\
\text { output of EE; Less } \\
\text { attention is being paid to } \\
\text { value capture; Central role } \\
\text { is executed by publicly } \\
\text { oriented (successful) } \\
\text { entrepreneurs with } \\
\text { long-term commitment to } \\
\text { the region [Felf, 2012]; } \\
\text { Value is created on an } \\
\text { individual basis; EE "can } \\
\text { be a breeding place" of } \mathrm{BE}\end{array}$ \\
\hline
\end{tabular}


Table 4 (continued)

\begin{tabular}{|c|c|c|c|c|c|c|}
\hline № & Author & Journal & LCS & LC, \% & Definition & Key features \\
\hline 4 & $\begin{array}{l}\text { [Brown, } \\
\text { Mason, } \\
2017]\end{array}$ & $\begin{array}{l}\text { Small Business } \\
\text { Economics }\end{array}$ & 28 & 5.92 & $\begin{array}{l}\text { No explicit definition is } \\
\text { provided. However, the } \\
\text { authors define EE through } \\
\text { its multi-relationality and } \\
\text { spatial embeddedness of } \\
\text { processes }\end{array}$ & $\begin{array}{l}\text { Entrepreneurial actors } \\
\text { serve as the heart of the } \\
\text { ecosystem; } \\
\text { Entrepreneurial resource } \\
\text { providers facilitate the } \\
\text { transition of resources } \\
\text { into growing firms; } \\
\text { Presence of platforms* for } \\
\text { collaboration; } \\
\text { Geographical proximity of } \\
\text { collaboration; Knowledge } \\
\text { exchange, which serves as } \\
\text { a basis for learning } \\
\text { processes; Entrepreneurs } \\
\text { and infrastructure serve } \\
\text { as a core actor of the EE }\end{array}$ \\
\hline 5 & $\begin{array}{l}\text { [Audretsch, } \\
\text { Belitski, } \\
\text { 2017] }\end{array}$ & $\begin{array}{l}\text { The Journal of } \\
\text { Technology } \\
\text { Transfer }\end{array}$ & 27 & 5.71 & $\begin{array}{l}\text { "...Institutional and } \\
\text { organizational as well as } \\
\text { other systemic factors } \\
\text { that interact and influence } \\
\text { identification and commer- } \\
\text { cialization of entrepre- } \\
\text { neurial opportunities" }\end{array}$ & $\begin{array}{l}\text { Geographic boundaries of } \\
\text { EE; Inter-dependency of } \\
\text { actors; Importance of } \\
\text { system-level context; } \\
\text { Dualism of EE (its } \\
\text { contextual domain and } \\
\text { individual decision-making } \\
\text { driven by perceived } \\
\text { assessment of the context) }\end{array}$ \\
\hline 6 & $\begin{array}{l}\text { [Pitelis, } \\
2012]\end{array}$ & $\begin{array}{l}\text { Industrial and } \\
\text { Corporate } \\
\text { Change }\end{array}$ & 22 & 4.65 & $\begin{array}{l}\text { No explicit definition is } \\
\text { provided (the paper itself } \\
\text { is more policy-oriented } \\
\text { and is concentrated upon } \\
\text { the study of clusters } \\
\text { phenomena) }\end{array}$ & - \\
\hline 7 & $\begin{array}{l}\text { [Spigel, } \\
\text { Harrison, } \\
2018]\end{array}$ & $\begin{array}{l}\text { Strategic } \\
\text { Entrepre- } \\
\text { neurship } \\
\text { Journal }\end{array}$ & 21 & 4.44 & $\begin{array}{l}\text { The paper provides an } \\
\text { exhaustive analysis of } \\
\text { entrepreneurial ecosystem } \\
\text { research, including its } \\
\text { antecedents - clusters } \\
\text { and regional innovation } \\
\text { systems (RIS) - with a } \\
\text { particular emphasis on the } \\
\text { differences of the EE } \\
\text { concept }\end{array}$ & $\begin{array}{l}\text { Consideration of the } \\
\text { ability of entrepreneurs to } \\
\text { access available resources; } \\
\text { inclusion of a particular } \\
\text { type of knowledge - } \\
\text { knowledge about the } \\
\text { entrepreneurial process; } \\
\text { EE is led by entrepreneurs } \\
\text { themselves; EE does not } \\
\text { have a strong relation to a } \\
\text { particular industry and/or } \\
\text { sector }\end{array}$ \\
\hline
\end{tabular}


Table 4 (end)

\begin{tabular}{|c|c|c|c|c|c|c|}
\hline № & Author & Journal & LCS & LC, \% & Definition & Key features \\
\hline 8 & $\begin{array}{l}\text { [Nambisan, } \\
\text { Baron, } \\
\text { 2013] }\end{array}$ & $\begin{array}{l}\text { Entrepre- } \\
\text { neurship } \\
\text { Theory and } \\
\text { Practice }\end{array}$ & 15 & 3.17 & $\begin{array}{l}\text { “...Entrepreneurs [...] must } \\
\text { manage their new ventures } \\
\text { while simultaneously } \\
\text { keeping in view different } \\
\text { sets of potentially conflict- } \\
\text { ing forces emanating from } \\
\text { the ecosystem" }\end{array}$ & - \\
\hline 9 & $\begin{array}{l}\text { [Solesvik, } \\
\text { Westhead, } \\
\text { 2019] } * *\end{array}$ & $\begin{array}{l}\text { Foresight and } \\
\text { STI } \\
\text { Governance }\end{array}$ & - & - & $\begin{array}{l}\text { The paper relies upon the } \\
\text { definition by [Malecki, } \\
2018, \text { p. 1]: “...Array of } \\
\text { dynamic social, institu- } \\
\text { tional, and cultural } \\
\text { processes as well as local } \\
\text { entities that stimulate and } \\
\text { foster the creation and } \\
\text { growth of new firms" }\end{array}$ & $\begin{array}{l}\text { New ventures as an output } \\
\text { of the ecosystem; Inter- } \\
\text { dependency of actors; } \\
\text { Importance of the context; } \\
\text { Geographical boundaries } \\
\text { of the ecosystem }\end{array}$ \\
\hline 10 & $\begin{array}{l}\text { [Chepurenko, } \\
\text { 2019] ** }\end{array}$ & $\begin{array}{l}\text { Foresight } \\
\text { and STI } \\
\text { Governance }\end{array}$ & - & - & $\begin{array}{l}\text { The paper defines EE as a } \\
\text { synonym of BE and relies } \\
\text { upon the definition by } \\
\text { [Moore, 1993] }\end{array}$ & - \\
\hline 11 & $\begin{array}{l}\text { [Trabskaja, } \\
\text { Mets, 2019] } \\
* *\end{array}$ & $\begin{array}{l}\text { Foresight and } \\
\text { STI } \\
\text { Governance }\end{array}$ & - & - & $\begin{array}{l}\text { “...System of interrelated } \\
\text { components, which deter- } \\
\text { mine possibilities and pace } \\
\text { of creation and scaling of } \\
\text { new stable business by } \\
\text { entrepreneurs...” }\end{array}$ & $\begin{array}{l}\text { New ventures as an output } \\
\text { of the ecosystem; Inter- } \\
\text { dependency of actors; } \\
\text { Geographical boundaries } \\
\text { of the ecosystem }\end{array}$ \\
\hline
\end{tabular}

Notes: * term "platform" in this case has a different meaning from that one applied by [Gawer, Cusumano, 2014] and means a physical and social place where entrepreneurs are able to meet and share their ideas, resources, etc.: business clubs, mentoring opportunities, start-up networks; ** included from the Russian papers sample.

ness and entrepreneurial ecosystems, therefore, allowed us to obtain an overall understanding of the essence of these phenomena. In particular, we were able to outline their internal logic and connections to the existing research domains. However, in order to demarcate these concepts, we need to study their ontological similarities and differences and understand whether they share similar ground and what their major distinctive features are.

\section{Ontological similarities and differences among innovation ecosystem, business ecosystem and entrepreneurial ecosystem} The conducted analysis of the innovation ecosystem, business ecosystem and entre- preneurial ecosystem literature revealed that despite having certain overlaps, these phenomena have certain distinctive features. Therefore, we conduct a comparative analysis of the IE, BE and EE concepts in order to explicitly outline their ontological similarities and differences (Table 5).

In order to do so, we will first outline a set of features, which will be used as a basis for comparison. This set of features is a result of the conducted in-depth analysis of the papers. When we carefully analyzed the papers in order to: (1) extract the definitions; and (2) to outline a list of features, which will adequately describe each of the phenomena, we noticed that scholars use to 
Table 5

Analysis of EE stream papers

\begin{tabular}{|c|c|c|c|}
\hline Feature & IE & BE & $\mathbf{E E}$ \\
\hline $\begin{array}{c}\text { Core element / } \\
\text { Actor }\end{array}$ & \begin{tabular}{|l} 
- Core innovator (focal \\
firm) - usually big \\
company) [Adner, \\
Kapoor, 2010] \\
- Focal firm [Adner, \\
Kapoor, 2010; Beck, \\
Gadzhaeva, 2018] \\
- Ecosystem leader \\
[Nambisan, Baron, \\
2013]
\end{tabular} & $\begin{array}{l}\text { Ecosystem leader - } \\
\text { usually big company, } \\
\text { who has access to big } \\
\text { audience of consumers } \\
\text { [Moore, 1993] } \\
\text { - Keystone company [Li, } \\
\text { 2009] } \\
\text { Central company - } \\
\text { usually big [Clarysse et } \\
\text { al., 2014; Gawer, } \\
\text { Cusumano, 2014] }\end{array}$ & 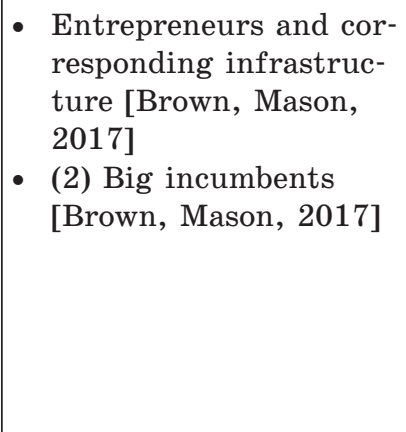 \\
\hline $\begin{array}{l}\text { Role of the core } \\
\text { element / Actor }\end{array}$ & $\begin{array}{l}\text { - Identification of com- } \\
\text { plementors, required } \\
\text { for the creation and de- } \\
\text { livery of the focal value } \\
\text { proposition [Adner, } \\
2006 \text { ] } \\
\text { - Creation of a core com- } \\
\text { ponent of the innova- } \\
\text { tion [Adner, 2006; } \\
\text { Adner, Kapoor, 2010; } \\
\text { 2016] } \\
\text { Elimination of innova- } \\
\text { tion (technological) bot- } \\
\text { tlenecks [Adner, } \\
\text { Kapoor, 2010; 2016] }\end{array}$ & $\begin{array}{l}\text { - Initiation of ongoing im- } \\
\text { provement [Moore, 1993] } \\
\text { - Sustaining collaboration } \\
\text { among participants } \\
\text { [Moore, 1993] } \\
\text { - Making important inno- } \\
\text { vative contributions to } \\
\text { the performance of eco- } \\
\text { system [Moore, 1993] } \\
\text { - Connecting participants } \\
\text { [Iansiti, Levien, 2004] } \\
\text { - Creating elements cru- } \\
\text { cial to the survival of } \\
\text { ecosystem [Iansiti, } \\
\text { Levien, 2004] } \\
\text { Coordination of activities } \\
\text { [Gawer, Cusumano, } \\
\text { 2014] }\end{array}$ & $\begin{array}{l}\text { - (1) Promotion of net- } \\
\text { working and collabora- } \\
\text { tion [Spigel, 2017] } \\
\text { - (1) Creation of environ- } \\
\text { ment, which encourages } \\
\text { a new round of entre- } \\
\text { preneurship [Autio et } \\
\text { al., 2014] } \\
\text { - (1) Identification of key } \\
\text { challenges [Spigel, } \\
\text { Harrison, 2018] } \\
\text { - (2) Incubation of entre- } \\
\text { preneurs [Brown, } \\
\text { Mason, 2017] }\end{array}$ \\
\hline $\begin{array}{l}\text { Types of partici- } \\
\text { pants (excl. core } \\
\text { element) }\end{array}$ & $\begin{array}{l}\text { - Suppliers, buyers, com- } \\
\text { plementors [Adner, } \\
\text { Kapoor, 2010; 2016] }\end{array}$ & $\begin{array}{l}\text { - Suppliers, complemen- } \\
\text { tors, customers [Gawer, } \\
\text { Cusumano, 2014; } \\
\text { Iansiti, Levien, 2004; } \\
\text { Kapoor, Lee, 2013; } \\
\text { Teece, 2007] }\end{array}$ & $\begin{array}{l}\text { - Entrepreneurs, suppli- } \\
\text { ers, buyers, state } \\
\text { [Audretsch, Belitski, } \\
\text { 2017; Solesvik, } \\
\text { Westhead, 2019; } \\
\text { Trabskaja, Mets, 2019] }\end{array}$ \\
\hline $\begin{array}{c}\text { Renewal mecha- } \\
\text { nisms }\end{array}$ & $\begin{array}{l}\text { Elimination of bottle- } \\
\text { necks (components and } \\
\text { complements) [Adner, } \\
\text { Kapoor, 2010] }\end{array}$ & $\begin{array}{l}\text { - Increase of meaningful } \\
\text { diversity [Iansiti, } \\
\text { Levien, 2004] } \\
\text { - Platform evolving } \\
\text { [Gawer, Cusumano, } \\
\text { 2014] }\end{array}$ & $\begin{array}{l}\text { - "Entrepreneurial re-cy- } \\
\text { cling" [Brown, Mason, } \\
\text { 2017] }\end{array}$ \\
\hline Boundaries & $\begin{array}{l}\text { - Determined by a flow of } \\
\text { activities relative to the } \\
\text { position of focal offer- } \\
\text { ing [Adner, Kapoor, } \\
2010 \text { ] }\end{array}$ & $\begin{array}{l}\text { Determined by the pro- } \\
\text { cess of creation and de- } \\
\text { livery of a focal VP [Li, } \\
2009]\end{array}$ & $\begin{array}{l}\text { - Determined by a par- } \\
\text { ticular geographical do- } \\
\text { main [Brown, Mason, } \\
\text { 2017; Spigel, 2017; } \\
\text { Solesvik, Westhead, } \\
\text { 2019; Trabskaja, Mets, } \\
\text { 2019] }\end{array}$ \\
\hline
\end{tabular}


Table 5 (continued)

\begin{tabular}{|c|c|c|c|}
\hline Feature & IE & BE & $\mathbf{E E}$ \\
\hline Target outcomes & $\begin{array}{l}\text { Creation of a bundle of } \\
\text { compatible innovative } \\
\text { offerings (from consum- } \\
\text { ers standpoint) [Adner, } \\
\text { Kapoor, 2010] }\end{array}$ & $\begin{array}{l}\text { - Shared value extraction } \\
\text { [Moore, 1993] } \\
\text { - } \text { Commercialization of a } \\
\text { new technology } \\
\text { [Kapoor, Lee, 2013] } \\
\text { - Addressing the needs of } \\
\text { the target customer } \\
\text { [Clarysse et al., 2014] } \\
\text { - Delivery of value to the } \\
\text { customer [Clarysse et } \\
\text { al., 2014] }\end{array}$ & $\begin{array}{l}\text { (New round of) entre- } \\
\text { preneurship [Acset al., } \\
\text { 2017; Solesvik, } \\
\text { Westhead, 2019; } \\
\text { Trabskaja, Mets, 2019] }\end{array}$ \\
\hline $\begin{array}{l}\text { Dynamics of } \\
\text { collaboration }\end{array}$ & $\begin{array}{l}\text { - Coopetition [Adner, } \\
\text { Kapoor, 2016; } \\
\text { Carayannis, Campbell, } \\
\text { 2009; Nambisan, Baron, } \\
\text { 2013; Rohrbeck, Holzle, } \\
\text { Gemunden, 2009] } \\
\text { - Co-evolution } \\
\text { [Carayannis, Campbell, } \\
\text { 2009; Nambisan, Baron, } \\
\text { 2013] } \\
\text { Co-specialization } \\
\text { [Carayannis, Campbell, } \\
\text { 2009] }\end{array}$ & $\begin{array}{l}\text { - } \text { Coopetition [Clarysse et } \\
\text { al., 2014; Moore, 1993] } \\
\text { - Co-evolution [Li, 2009; } \\
\text { Moore, 1993; Teece, } \\
\text { 2007] } \\
\text { - Adaptation [Kapoor, } \\
\text { Lee, 2013] } \\
\text { - Specialization within } \\
\text { the ecosystem [Clarysse } \\
\text { et al., 2014; Iansiti, } \\
\text { Levien, 2004] }\end{array}$ & $\begin{array}{l}\text { - Collaboration [Acs et } \\
\text { al., 2017] } \\
\text { - Value creation at an in- } \\
\text { dividual level [Acs et } \\
\text { al., 2017] } \\
\text { - Socio-spatial context as } \\
\text { a mediator of entrepre- } \\
\text { neurship [Brown, } \\
\text { Mason, 2017] } \\
\text { - Absence of direct com- } \\
\text { petition among startups } \\
\text { within the EE [Spigel, } \\
\text { Harrison, 2018] }\end{array}$ \\
\hline $\begin{array}{c}\text { Nature of interde- } \\
\text { pendence }\end{array}$ & $\begin{array}{l}\text { - Technological } \\
\text { [Carayannis, Campbell, } \\
\text { 2009] (including com- } \\
\text { mon core technology; } \\
\text { compatibility of compo- } \\
\text { nents) [Adner, Kapoor, } \\
\text { 2010;2016] }\end{array}$ & $\begin{array}{l}\text { - Determined by the value } \\
\text { chain of delivery both fo- } \\
\text { cal VP and complement- } \\
\text { ing elements [Clarysse et } \\
\text { al., 2014; Iansiti, Levien, } \\
\text { 2004; Kapoor, Lee, 2013; } \\
\text { Li, 2009] } \\
\text { - Financial (financial per- } \\
\text { formance of an ecosystem } \\
\text { member to a certain ex- } \\
\text { tent depends upon the } \\
\text { overall ecosystem health } \\
\text { [Kapoor, Lee, 2013; } \\
\text { Teece, 2007]; coordinated } \\
\text { investments [Kapoor, } \\
\text { Lee, 2013]) }\end{array}$ & $\begin{array}{l}\text { - Determined by the en- } \\
\text { trepreneurial process } \\
\text { [Brown, Mason, 2017] } \\
\text { - Cultural (entrepreneuri- } \\
\text { al mindset and environ- } \\
\text { ment) [Brown, Mason, } \\
\text { 2017; Solesvik, } \\
\text { Westhead, 2019] } \\
\text { - Financial (capital for } \\
\text { venture development) } \\
\text { [Brown, Mason, 2017] } \\
\text { - Knowledge processing } \\
\text { mechanisms [Spigel, } \\
\text { Harrison, 2018] }\end{array}$ \\
\hline Challenges & $\begin{array}{l}\text { Leadership (division of } \\
\text { roles) [Adner, 2006] } \\
\text { (Technological) integra- } \\
\text { tion and interdepend- } \\
\text { ence [Adner, 2006; } \\
\text { Adner, Kapoor, 2010; } \\
\text { Nambisan, Baron, 2013; } \\
\text { Ritalaet al., 2013] }\end{array}$ & 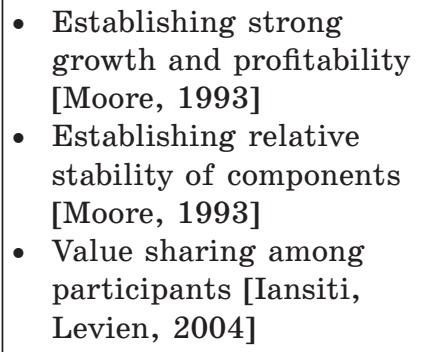 & $\begin{array}{l}\text { - (1) Related to venture } \\
\text { creation } \\
\text { - (2) Choice of firms for } \\
\text { investments [Brown, } \\
\text { Mason, 2017] }\end{array}$ \\
\hline
\end{tabular}


Table 5 (end)

\begin{tabular}{|c|c|c|c|}
\hline Feature & IE & BE & $\mathbf{E E}$ \\
\hline Shared elements & \begin{tabular}{|l|} 
- \\
ogmplementary technol- \\
[Nambisan, Baron, \\
2013] \\
- Common set of goals \\
(value proposition) and \\
objectives [Nambisan, \\
Baron, 2013; Ritala et \\
al., 2013] \\
Common knowledge \\
[Adner, Kapoor, 2010]
\end{tabular} & $\begin{array}{l}\text { - Platform [Adner, } \\
\text { Kapoor, 2010; Clarysse } \\
\text { et al., 2014; Gawer, } \\
\text { Cusumano, 2014; } \\
\text { Iansity, Levien, 2004; } \\
\text { Li, 2009; Teece, 2007] } \\
\text { - Available resources } \\
\text { [Clarysseet al., 2014] }\end{array}$ & $\begin{array}{l}\text { - Core technology [Spigel, } \\
\text { 2017] } \\
\text { - Knowledge on challeng- } \\
\text { es of growing a venture } \\
\text { [Spigel, 2017] } \\
\text { - Resources and culture } \\
\text { of the domain [Acs et } \\
\text { al., 2017] } \\
\text { Knowledge about the } \\
\text { entrepreneurial process } \\
\text { [Spigel, Harrison, 2018] }\end{array}$ \\
\hline $\begin{array}{l}\text { Major reason for } \\
\text { collaboration }\end{array}$ & $\begin{array}{l}\text { Access to the shared } \\
\text { pool of knowledge and } \\
\text { expertise [Adner, } \\
\text { Kapoor, 2010] } \\
\text { - Collective development } \\
\text { of innovative offering } \\
\text { in order to compete } \\
\text { with other companies/ } \\
\text { ecosystems [Adner, } \\
\text { Kapoor, 2010] }\end{array}$ & $\begin{array}{l}\text { - Competition with other } \\
\text { companies/ecosystems } \\
\text { [Moore, 1993] } \\
\text { - Leveraging available re- } \\
\text { sources and recombin- } \\
\text { ing them in order to de- } \\
\text { liver new VP to custom- } \\
\text { ers [Clarysse et al., } \\
2014]\end{array}$ & $\begin{array}{l}\text { Acquisition of resourc- } \\
\text { es, knowledge, and sup- } \\
\text { port, which increase } \\
\text { competitive advantage } \\
\text { and ability to scale up } \\
\text { [Spigel, Harrison, 2018] }\end{array}$ \\
\hline
\end{tabular}

apply a rather similar set of descriptors to explain the essence of these concepts. In particular, they stressed features like a core element and its role within the ecosystem; composition of participants, nature of their collaboration and the reason for participation; goal of the ecosystem existence; shared resources (if any). We carefully coded these elements and checked the comparison list for consistency. If any feature was not mentioned in a particular stream of the ecosystem research, we excluded it from the list. Table 5 includes a final (consistent) list of features, which was used to compare IE, BE and EE.

As we can see, the observed concepts can be distinguished from each other by a number of indicators. In particular, the IE concept is mostly concentrated upon the mechanisms of joint creation of value (in a form of various innovational offerings) with the corresponding collaborative exploitation of common resources and knowl- edge base. Therefore, the outcome of such collaboration may be considered in terms of a portfolio of innovative technologies/ products/services, which is impossible to create by virtue of a single firm or a small group of firms. A particular importance in this sense is concentrated in hands of complementors and consumers who provide valuable inputs in terms of knowledge and resources. At the same time, the major reason for collaboration within the innovation ecosystem is the pursue of benefits in a form of access to the existing pool of knowledge and capabilities.

The BE concept is more concentrated upon the process of collective extraction of value, which is created by virtue of collaboration among economic agents. As such the major role of this ecosystem is concluded in the collective delivery of VP to the customer in a form of both a focal product/service/technology and important complementary offerings. Therefore, the main reason for col- 
laboration is to leverage available resources and, if possible, recombine them into a new VP, which will be desired by the consumer and, consequently, yield positive returns. The role of a focal actor in BE is more concentrated upon the economic side of the collaboration process and is devoted to the establishment of favorable conditions for participants to cooperate - usually by virtue of the incorporated platform.

The concept of EE stands a little bit aside from the other two as it draws heavily upon theories of entrepreneurship, economic geography and regional science [Spigel, Harrison, 2018]. The major focus in EE is aimed at the investigation of underlying processes of new ventures creation. That is the major reason why many works from the EE stream are talking about cultural and social attributes of this process. The central role is assigned to the community of entrepreneurs and the corresponding infrastructure, and the overall process is studied as a constellation of individual value creations that collectively lead to accumulation of necessary conditions for a new round of entrepreneurship.

Basing upon the conducted literature review we may state the following: there is a much broader concept of ecosystem, which may serve as a conceptual "umbrella" for all the investigated types of ecosystems. In particular, it provides a common biological origin [Adner, 2017] for such type of collaboration of economic agents and allows uniting the overlapping aspects of the examined concepts of IE, BE and EE. As it was already shown in the paper by [Jacobides, Cennamo, Gawer, 2018, p. 2258] ecosystems in general “...require providers of complementary innovations, products, or services, who [...] need not be bound by contractual arrangements - but have significant interdependence nonetheless". At the same time notions of IE, BE and EE highlight a particular set of features essential for understanding the process of interfirm collaboration. In particular, innovation ecosystem can be described as a network of legally independent economic agents of varying line-up, who can be direct competitors, however, collaborate for the purpose of creating a comprehensive VP for the customer. Business ecosystem comprises a phenomenon when focal actor tries to expand the boundaries of his offering through the development and maintaining an ecosystem of participants who are able to provide him with complementary offerings and participate in the development of this offering. Entrepreneurial ecosystem is focused upon the creation of a network of interrelated economic agents, concentrated within a particular geographical area, which ultimately will result in the creation of new enterprises and stimulation of regional development.

From our standpoint the observed situation (when ecosystem literature provides a number of research avenues) does not seem to be contradictory or redundant - until there is general agreement among scholars upon the internal meaning of the studied concepts, the theory on ecosystems will develop and evolve. An increasing complexity of the environment and pace of changes lead to a tighter cooperation among economic agents, who usually do not have time to develop complicated market- or hierarchybased mechanisms of interaction, whereas the ecosystem literature provides valuable solutions.

Therefore, the obtained results allow us to tackle the existing controversy in usage of the ecosystem term and provide a more rigorous definition of the object of studies. In particular, the conducted bibliometric and in-depth analysis of publications as well as the comparative analysis of the IE, BE and EE concepts allowed us to clarify their essence and to better demarcate them from ontological perspective. The results of our study may serve as a basis for future research in this domain - in particular, scholars may employ our approach to clearly define the object of their studies that will ultimately result in a less chaotic development of the ecosystem theory [Adner, 2017]. 


\section{CONCLUSION, DISCUSSION AND RESEARCH LIMITATION}

The aim of this paper is to provide a greater transparency to the existing research on ecosystems and in particular to demarcate three tightly connected phenomena of innovation ecosystem, business ecosystem and entrepreneurial ecosystem, which create a great deal of controversy in the existing body of knowledge. In order to do so, we applied a mixed approach, which included both bibliometric and in-depth analysis of the publications from these research domains. We base our findings on the publications from WoS database over the period of 1993-2020. The bibliometric analysis of 777 studies devoted to the concepts of IE, BE and EE allowed us to develop a preliminary understanding of the studied concepts and construct three corresponding samples of the total size of $32 \mathrm{pa}^{-}$ pers, which were used in the in-depth analysis.

First, we focused our attention on the investigation of the essence of these concepts. The existing body of research provides a rather fragmented and contradictory explanation of their similarities and differences. In particular, there are scholars who treat IE and BE synonymously (e.g.: [Adner, Kapoor, 2016; Brusoni, Precipe, 2013; Nambisan, Baron, 2013; Ritala et al., 2013; Rohrbeck, Holzle, Gemunden, 2009]), while the research of EE sometimes treats it as a part of IE or BE (e.g.: [Acs et al., 2017; Chepurenko, 2019]). Altogether, this creates a conceptual ambiguity and results in a fair amount of criticism towards the notion of ecosystem [Oh et al., 2016]. Therefore, in our research we tried to tackle these issues by conducting both the bibliometric analysis of the papers devoted to these three tightly connected streams of the ecosystem research and their in-depth investigation.

In particular, we focused our attention on establishing connections between IE, BE and $\mathrm{EE}$ and the existing well-established managerial categories. This allowed us to answer the question regarding their theo- retical foundations and provide a more structured (less chaotic [Adner, 2017]) picture of the existing body of knowledge on ecosystems. In particular, the obtained results of the constructed three-fields plot and cooccurrence networks allowed us to visualize and cluster existing studies on IE, BE and $\mathrm{EE}$ and served as a basis for further ontological analysis. We then continued with the construction of their respective research domains by developing co-occurrence networks. This allowed us to obtain a preliminary understanding of the IE, BE and EE essence and proceed with the in-depth investigation of the most relevant papers within each of the ecosystem streams.

Our results suggest that: (1) innovation ecosystem can be described as a network of legally independent economic agents of varying line-up who can be direct competitors, however, collaborate for the purpose of creating a comprehensive VP for the customer; (2) business ecosystem comprises a phenomenon when a focal actor tries to expand the boundaries of his offering through developing and maintaining an ecosystem of participants who are able to provide complementary VPs and participate in the development of this offering; and (3) entrepreneurial ecosystem is focused upon the creation of a network of interrelated economic agents, concentrated within a particular geographical area, which ultimately will result in the creation of new enterprises and stimulation of regional development. These results allow for a better understanding of the IE, BE and EE concepts and serve as a foundation for a more rigorous theory of ecosystem [Oh et al., 2016].

Second, we tackled the issue of ontological similarities and differences among three tightly connected phenomena: innovation ecosystem, business ecosystem and entrepreneurial ecosystem. The existing body of knowledge does not provide a clear demarcation of these concepts and many papers treat them synonymously. However, the conducted analysis allowed us to (1) outline distinctive features of all three concepts; and (2) 
to conduct a thorough comparative analysis based upon a set of stable descriptors retrieved from the papers of the sample, which outlined a number of differences. In particular, as opposed to IE, BE is more concentrated upon the extraction of the existing value [Adner, Kapoor, 2010; Moore, 1993] by means of organizing a corresponding network of complementors and coordinating their efforts [Adner, Kapoor, 2010]. At the same time, the notion of EE stands a little bit aside from the other two concepts and is mostly concentrated upon the creation of environment, which would stimulate the development of new ventures [Acs et al., 2017; Solesvik, Westhead, 2019; Trabskaja, Mets, 2019]. However, the conducted analysis also allowed us to reveal certain commonalities for the studied concepts, determined by a broader umbrella concept of ecosystem, which to a great extent explains the observed overlap in their meanings.

Overall, we have contributed to the existing ecosystem literature by identifying the essence of innovation, business and entrepreneurial ecosystems in terms of their boundaries and common theoretical foundations. The conducted comparative analysis allowed us to show similarities and differences of these concepts in terms of their components. This allowed us to come up with clear definitions for these types of ecosystems and demarcate the existing ecosystem research streams. Taken together, this will allow future scholars to better position their research by clearly defining the object of their analysis that will ultimately result in a more structured and transparent development of the ecosystem theory. In particular, further studies of the IE, BE and $\mathrm{EE}$ concepts may adopt the proposed definitions and use them to clearly indicate the boundaries of the studied phenomena. This will bring a greater clarity to the existing research on ecosystems and may help to provide meaningful arguments for the existing discussion on the essence of the ecosystem concept.

The results of this study could have interesting implications for practitioners as well, especially ecosystem orchestrators. The explored features of the three studied concepts may be particularly interesting, as they provide a set of guidelines on what is more important in terms of coordination and support of various types of ecosystems. Depending upon the perceived goal and knowing the internal mechanics of different types of ecosystems, a keystone company is able to focus its efforts on activities with the biggest added value, which will ultimately result in a better performance of the whole ecosystem and bring benefits to all actors involved. Such focused efforts may trigger a reinforcing loop when appropriate actions performed by the ecosystem leader attract new participants, which consequently increases the value of the ecosystem itself and provides a tangible rationale for supporting the ecosystem.

At the same time, this research implies a number of limitations. First, bibliometric analysis being mechanical in its nature cannot underline certain shades of meaning, which may be important in the conditions of the ongoing debate about the concept of ecosystem [Oh et al., 2016]. Second, indepth analysis of papers by its definition, despite providing a very detailed look into selected papers, means the establishment of certain boundaries, which may narrow the understanding of the studied phenomena. And finally, the overall rise of references in academic literature could create certain biases in the obtained results.

This research provides certain clarification to the existing conceptual mix in the field of the ecosystem research and can be used as a foundation for further investigation of the concept. In particular, we found a few potentially fruitful avenues for future research. First, a notion of ecosystem boundaries seems to be of great interest. Taking into account the dynamic nature of the concept, it is important to understand the limits of the studied phenomenon. This may decrease the existing level of criticism of the ecosystem concept by providing more clarity on its scope and position within the socio-economic environment. Second, a dy-

PЖM 18 (1): 73-102 (2020) 
namic aspect of the ecosystem existence seems to be a promising avenue for research. Considering the variable nature of interdependence, constellation of participants and coordination mechanisms, understanding the underlying dynamics of these processes

\section{REFERENCES}

Acs Z., Stam E., Audretsch D., O'Connor A. 2017. The lineages of the entrepreneurial ecosystem approach. Small Business Economics 49 (1): 1-10.

Adner R. 2006. Match your innovation strategy to your innovation ecosystem. Harvard Business Review 84 (4): 98-107.

Adner R. 2017. Ecosystem as structure: An actionable construct for strategy. Journal of Management 43 (1): 39-58.

Adner R., Kapoor R. 2010. Value creation in innovation ecosystems: How the structure of technological interdependence affects firm performance in new technology generations. Strategic Management Journal 31: 306-333.

Adner R., Kapoor R. 2016. Innovation ecosystems and the pace of substitution: $\mathrm{Re}^{-}$ examining technology s-curves. Strategic Management Journal 37: 625-648.

Aria M., Cuccurullo C. 2017. Bibliometrix: An R-tool for comprehensive science mapping analysis. Journal of Infometrics $\mathbf{1 1}$ (4): 959-975.

Audretsch D., Belitski M. 2017. Entrepreneurial ecosystems in cities: Establishing the framework conditions. Journal of Technology Transfer 42: 1030-1051.

Autio E., Kenney M., Mustar P., Siegel. D., Wright M. 2014. Entrepreneurial innovation: The importance of context. Research Policy 43: 1097-1108.

Ball R., Tunger D. 2006. Science Indicators revisited-Science Citation Index versus Scopus: A bibliometric comparison of both citation databases. Information Services \& Use 26 (4): 293-301. will provide a greater insight in the ecosystem concept. Third, more empirical research is required so that we could operate not only with the conceptual elements of the phenomena but also base the corresponding discussion upon hard facts.

Beck N., Gadzhaeva L. 2018. Open innovation business models and open strategies: Features, challenges, development prospects. Bulletin of Moscow University: Series 6. Economics 1: 140-159. (In Russian)

Brown R., Mason C. 2017. Looking inside the spiky bits: A critical review and conceptualisation of entrepreneurial ecosystems. Small Business Economics 49: 11-30.

Brusoni S., Prencipe A. 2013. The organization of innovation in ecosystems: Problem framing, problem solving, and patterns of coupling. Advances in Strategic Management 30: 167-194.

Carayannis E., Campbell D. 2009. "Mode 3" and "Quadruple Helix": Toward a 21st century fractal innovation ecosystem. International Journal of Technology Management 46 (3/4): 201-234.

Chepurenko A. 2019. Entrepreneurship ecosystems in post-socialist economies. Foresight and STI Governance 13 (4): 6-8. (In Russian)

Chesbrough H. 2003. The logic of open innovation: Managing intellectual property. California Management Review 45 (3): 33-58.

Christensen C., Rosenbloom R. 1995. Explaining the attacker's advantage: Technological paradigms, organizational dynamics, and the value network. Research Policy 24 (2): 233-257.

Clarysse B., Wright M., Bruneel J., Mahajan A. 2014. Creating value in ecosystems: Crossing the chasm between knowledge and business ecosystems. Research Policy 43: 1164-1176. 
Cobo M., Lopez-Herrera A., Herrera-Viedma E., Herrera F. 2011. An approach for detecting, quantifying, and visualizing the evolution of a research field: A practical application to the Fuzzy Sets Theory field. Journal of Informetrics 5: 146-166.

Creswell J. 2009. Research Design. Qualitative, Quantitative, and Mixed Method Approaches. SAGE Publications Inc.: California.

Felf B. 2012. Start-up Communities: Building an Entrepreneurial Ecosystem in Your City. John Wiley \& Sons: NJ.

Fjeldstad O., Show C., Miles R., Lettl C. 2012. The architecture of collaboration. Strategic Management Journal 33: 734-750.

Garfield E. 1990. Keywords Plus®: ISI's breakthrough retrieval method. Part 1. Expanding your searching power on Current Contents on Diskette. Current Contents ${ }^{\circledR} 1$ (32): 5-9.

Garfield E., Sher I.H. 1993. Keywords PlusTM algorithmic derivative indexing. Journal of the American Society for Information Science 44 (5): 298-299.

Gawer A., Cusumano M. 2014. Industry platforms and ecosystem innovation. Journal of Product Innovation Management 31 (3): 417-433.

Gomes L., Facin A., Salerno M., Ikenami R. 2018. Unpacking the innovation ecosystem construct: Evolution, gaps and trends. Technological Forecasting \& Social Change 136: 30-48.

Greenhalgh T., Robert G., Macfarlane F., Bate P., Kyriakidou O., Peacock R. 2005. Storylines of research in diffusion of innovation: A meta-narrative approach to systematic review. Social Science \& Medicine 61: 417-430.

He Q. 1998. Knowledge discovery through coword analysis. Library Trends 48 (1): 133159.

Hicks D., Wang J. 2011. Coverage and overlap of the new social sciences and humanities journal lists. Journal of the Association for Information Science and Technology 62 (2): 284-294.

Iansiti M., Levien R. 2004. Strategy as ecology. Harvard Business Review 82 (3): 6878.
Ikpaahindi L. 1985. An overview of bibliometrics - its measurements, laws and their applications. Libri 35 (2): 163-177.

Isenberg D. 2010. How to start an entrepreneurial revolution. Harvard Business Review 88 (6): 40-50.

Jacobides M., Cennamo C., Gawer A. 2018. Towards a theory of ecosystems. Strategic Management Journal 38: 2255-2276.

Kapoor R., Lee J.-M. 2013. Coordinating and competing in ecosystems: how organizational forms shape new technology investments. Strategic Management Journal 34: 274-296.

Lee S., Nam Y., Seonmi S., Son H. 2016. Determinants of ICT innovations: a cross-country empirical study. Technological Forecasting and Social Change 110: 71-77.

Li Y.-R. 2009. The technological roadmap of Cisco's business ecosystem. Technovation 29: 379-386.

Moore J. 1993. Predators and prey: new ecology of competition. Harvard Business Review 71 (3): 75-86.

Nambisan S., Baron A. 2013. Entrepreneurship in innovation ecosystems: Entrepreneurs' self-regulatory processes and their implications for new venture success. $E n$ trepreneurship Theory and Practice 37 (5): 1071-1097.

Oh D.-S., Phillips F., Park S., Lee E. 2016. Innovation ecosystems: A critical examination. Technovation 54: 1-6.

Overholm H. 2015. Collectively created opportunities in emerging ecosystems: The case of solar service ventures. Technovation 39-40: 14-25.

Pitelis C. 2012 . Clusters, entrepreneurial ecosystem co-creation, and appropriability: A conceptual framework. Industrial and Corporate Change 21 (6): 1359-1388.

Prahalad C. 2005. The Fortune at the Bottom of the Pyramid. Pearson Education: New Delhi.

Ritala P., Agouridas V., Assimakopoulos D., Gies O. 2013. Value creation and capture mechanisms in innovation ecosystems: A comparative case study. International Journal of Technology Management 63 (3/4): 244-267. 
Rohrbeck R., Holzle K., Gemunden H. 2009. Opening up for competitive advantage How Deutsche Telekom creates an open innovation ecosystem. $R \& D$ Management 39 (4): 420-430.

Ruker-Shaeffer P., Fischer B., Queiroz S. 2018. Beyond education: The role of research universities in innovation ecosystems. Foresight and STI Governance 12 (2): 50-61. (In Russian)

Simchi-Levi D. 2005. Designing and Managing the Supply Chain. McGraw-Hill College: NY.

Spigel B. 2017. The relational organization of entrepreneurial ecosystems. Entrepreneur ship Theory and Practice 41 (1): 49-72.

Spigel B., Harrison R. 2018. Toward a process theory of entrepreneurial ecosystems. Strategic Entrepreneurship Journal 12 (1): 151168.

Solesvik M., Westhead P. 2019. Fostering of Entrepreneurship Competencies and Entrepreneurial Intentions in a Weak Ecosystem. Foresight and STI Governance 13 (4): 60-68. (In Russian)
Teece D. 2007. Explicating dynamic capabilities: The nature and microfoundations of (sustainable) enterprise performance. Strategic Management Journal 28: 1319-1350.

Trabskaja J., Mets T. 2019. Ecosystem as the source of entrepreneurial opportunities. Foresight and STI Governance 13 (4): 1022. (In Russian)

Walrave B., Talmar M., Podoynitsyna K., Romme A., Verbong G. 2018. A multi-level perspective on innovation ecosystems for pathbreaking innovation. Technological Forecasting \& Social Change 136: 103-113.

Weber M., Hine M. 2015. Who inhabits a business ecosystem? The technospecies as a unifying concept. Technology Innovation Management Review 5 (5): 31-44.

Zhang J., Huo Y., Liang X.-J. 2008. Business ecosystem strategies of mobile network operators in the $3 \mathrm{G}$ era: The case of China Mobile. China Communications 5 (3): 114-118.

Zupic I., Cater T. 2015. Bibliometric methods in management and organization. Organizational Research Methods 18 (3): 429472.

Initial Submission: February 12, 2020

Final Version Accepted: March 29, 2020

\section{Содержательньй анализ концепций «экосистела инноваций", "бизнес-экосистела" и "предпринилательская экосистела"}

\section{Е. Д. Бурда, И. О. Волкова, Е. В. Гаврикова}

Факультет бизнеса и менеджмента, Национальный исследовательский университет «Высшая школа экономики», Москва, Россия

На протяжении последнего десятилетия в академической литературе наблюдается значительный рост публикаций, посвященных изучению концепции экосистем. Это привело к возникновению различных направлений исследований и соответствующей фрагментации терминологии рассматриваемой проблемы. Существующее множество трактовок и противоречивых определений обусловливает необходимость тщательного обзора исследований трех тесно связанных концепций: экосистемы инноваций, бизнес-экосистемы и предпринимательской экосистемы. Представленная работа основана на смешанной технике, комбинирующей библиометрический и глубинный анализ публикаций, посвященных изучению данных направлений. На основе исследования их теоретических предпосылок, формирования концептуальных структур и тщательного анализа в статье определено содержание понятий «экосистема инноваций», 
«бизнес-экосистема» и «предпринимательская экосистема», а также выделены их отличительные особенности. Кроме того, проведен сравнительный анализ данных концепций, что позволило выявить существующие сходства и разграничить их с онтологической точки зрения. Данная работа предоставляет определенное пояснение концептуального смешения в исследованиях, посвященных экосистемам, и может быть использована в качестве основы для дальнейшего изучения концепции.

Ключевые слова: экосистема, экосистема инноваций, бизнес-экосистема, предпринимательская экосистема, создание ценности, библиометрический анализ, соконкуренция.

JEL: M13, O30, O36.

For citation: Burda Y. D., Volkova I. O., Gavrikova E. V. 2020. Meaningful analysis of innovation, business and entrepreneurial ecosystem concepts. Russian Management Journal 18 (1): 73-102.

Статья поступила в редакцию 12 февраля 2020 г. Принята к публикации 29 лиарта 2020 г. 